\title{
Tissue Engineering of Craniofacial Tissues - A Review
}

\author{
Amol Somaji Patil ${ }^{1 *}$, Yash Merchant ${ }^{2}$ and Preethi Nagarajan ${ }^{3}$ \\ *Correspondence: amolp66@yahoo.com \\ ${ }^{1}$ Associate Professor, Department of Orthodontics, Bharati Vidyapeeth Dental College and Hospital, Pune, Mahrashtra, India. \\ IIntern, Bharati Vidyapeeth Dental College and Hospital, Pune, Mahrashtra, India. \\ ${ }^{3}$ Director, My Dentist, Mumbai, India.
}

\begin{abstract}
Engineering of craniofacial tissues would have a profound impact on various treatment strategies in dentistry. The role of mesenchymal stem cells in the formation of all craniofacial and dental structures has been well demonstrated. Stem cells from various craniofacial structures like dental epithelium, dental follicle, apical papilla, exfoliated deciduous teeth, periodontal ligament and dental pulp are readily accessible and have immense potential in craniofacial research for regenerative and tissue engineering applications. Various signalling molecules that pattern the morphogenesis of craniofacial tissues have been explored. This review article epitomises how dentistry should evolve and highlights the need for close partnerships between basic and clinical scientists.
\end{abstract}

Keywords: Tissue engineering, dentistry, stem cell, dental papilla, dental follicle, dental pulp stem cells

\section{Introduction}

A cadre of craniofacial tissue engineers with interdisciplinary skills in stem cell biology, genetics and molecular biology, materials science and mechanical engineering, as well as a clinical knowledge of dental, oral and craniofacial disorders is needed to advance the field of craniofacial tissue engineering. Biologically, mesenchymal cells are primarily responsible for the formation of virtually all dental, oral and craniofacial tissues and have been demonstrated to generate these key structures. Many dental and craniofacial structures are readily accessible, thus presenting a convenient platform for biologists, bioengineers and clinicians to test tissue-engineered prototypes $[1,2]$. Strategically, tissue engineering technologies pioneered outside the dental community have a profound implication on dental practice.

When shifting rehabilitation strategies from prosthetic to regenerative - such as with a tissue engineering approach-one must deal with the uniqueness of the craniofacial structures in their development and function. In the fields of maxillofacial surgery and periodontics, tissue engineering has been used to generate alveolar bone [3] and to regenerate oral tissues lost to cancer, decay, and periodontitis [4]. Cultured human dental pulp and gingival fibroblasts adhere to biodegradable scaffolds, and proliferate and differentiate in vitro $[5,6]$ and in vivo [7]. While aiming high at tadpole-style regeneration [8], a cell-based therapy could bring about the regeneration of a complete fully functional tooth composed of enamel instead of ceramic, dentin instead of composite, pulp instead of guttapercha and root/periodontium instead of a titanium fixture. Successful bioengineering of whole tooth crowns composed of accurately formed enamel, dentin, and pulp tissues has been reported [9]. A tissue engineering approach could treat devastating craniofacial congenital malformations, such as clefts and craniosynostosis, freeing children from the morbidity of the actual treatment [10].

Tissue engineering is generally considered to consist of three key components: (i) stem/progenitor cells, (ii) signaling molecules and (iii) a scaffold or extracellular matrix (ECM) which has been represented in Figure 1.

\section{Stem cells}

\section{Mesenchymal Stem Cells (MSCs)}

MSCs are self-renewable and have been experimentally differentiated into all mesenchymal or connective tissue lineages $[11,12]$ and, in many cases, have been used to engineer the craniofacial structures that their prenatal predecessors, mesenchymal cells, are capable of generating during development.

The capacity of MSCs in the de novo formation and/or regeneration of craniofacial structures is too natural an endeavour to make one wonder why this potential has not been exploited substantially up until the past decade. MSCs have been reported to differentiate into hepatic [13], renal [14], cardiac [15], and neural cells [16,17].

Whether highly purified or cloned MSC populations are necessarily needed for the engineering of craniofacial structures is not clear. Stem cell populations that generate native craniofacial structures, such as the mandibular joint, are heterogeneous and likely include both mesenchymal and hematopoietic stem cells. The morphogenesis of the articular condyle requires stem cells, chondrocytes and osteoblasts in addition to angiogenesis [18]. Second, host cell invasion and stem cell homing are likely inevitable in porous biomimetic scaffolds that are used as carriers for delivering stem cells and/ 


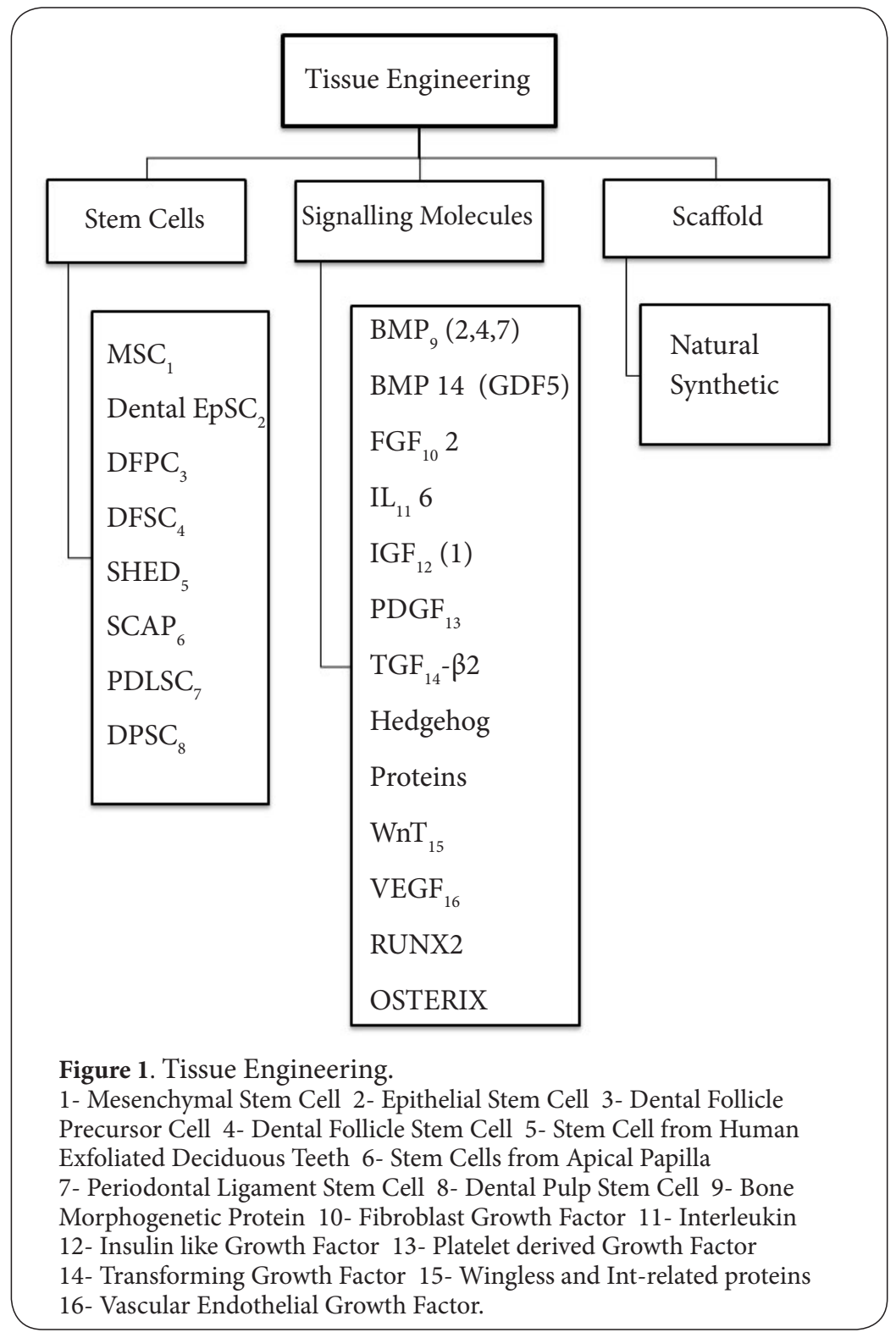

or stem-cell-derived tissue-forming cells $[19,20]$.

\section{Dental Epithelial Stem Cells (EpSC)}

The concept that teeth can be formed from primordia derived in vitro from non-dental cultured cells is an important step in the tissue engineering of teeth for replacement. However, this approach relies on the ability of such embryonic primordia to develop into the complete organ when transferred to the adult. The development of an embryonic primordium into a tooth in the adult jaw can be a unique idea [21].

The embryonic oral epithelium is a simple, two-cell-thick ectoderm. This epithelium can be engineered to express the appropriate signals to initiate odontogenesis to engineer a complete tooth primordium entirely from cultured cells. The identification of stem cells in dental pulp and from exfoliated deciduous teeth also raises the possibility that a patient's own tooth cells could be used to generate new tooth primordia $[22,23]$. The ability to tissue-engineer an organ rudiment such as a tooth primordium constitutes a major component of a regenerative medicine procedure [24]. However, such organ primordia must be capable of developing into the complete organ in situ, in the appropriate site in the adult body. The renal capsule and anterior chamber of the eye are two adult sites that have been routinely used to support ectopic organ and tissue development, because they are immune-compromised and can provide an adequate blood supply to the transplanted tissue. To date, there have been no demonstrations of development of a complete organ at its normal location in the adult body following transplantation of an embryonic primordium. However, seeding cultured 
tooth germ cells on bio-degradable scaffolds and then implanting them has successfully resulted in bioengineering tooth tissues [25].

Non-dental mesenchymal cells, when placed in contact with embryonic oral epithelium and transplanted to an ectopic site, generated tooth structure [26]. This report is pivotal in that it demonstrates that uncommitted MSC, in association with oral epithelium, can be instructed to mimic developmental events leading to growth of a tooth structure comprised of enamel, dentin, and pulp with a morphology resembling that of a natural tooth. These observations offer exciting opportunities for replacement of natural teeth damaged through disease or trauma and for those missing in hypodontia. There are obvious practical obstacles still to be overcome before this might be available as a routine clinical treatment, but it provides an elegant example of the translation of basic science research to the clinical arena.

The rodent incisor is a unique model for studying dental EpSC since, in contrast to human incisors or other vertebrates, this tooth grows throughout life. An EpSC niche, which is located in the apical part of the rodent incisor epithelium (cervical loop area), is responsible for a continuous enamel matrix production [27-31]. In this highly proliferative area, undifferentiated epithelial cells migrate toward the anterior part of the incisor and give rise to ameloblasts [32].

Dental EpSC can be isolated from post-natal teeth but exhibit complex problems that strongly limit their clinical application in humans. Ideally alternative sources should be easily accessible, available from adult individuals and the derived cells must have potential for enamel matrix production. The use of non-dental EpSC will only be possible with the transfer of genes, creating an odontogenic potential to nondental epithelia prior to any association with mesenchymal cells. This is certainly one of the most exciting goals of the next decade in tooth engineering [32].

Making entire teeth with enamel and dentin structures in vivo is a reality and not a utopia. However, these bioengineered teeth have been produced in ectopic sites and are still missing some essential elements such as the complete root and periodontal tissues that allow correct anchoring into the alveolar bone. In a unique study proposed for growing teeth in the mouse mandible, epithelial and mesenchymal cells were sequentially seeded into a collagen gel drop and then implanted into the tooth cavity of adult mice. With this technique the presence of all dental structures such as ameloblasts, odontoblasts, dental pulp, blood vessels, crown, PDL, root and alveolar bone could be observed [33]. Thus, the implantation of these tooth germs in the mandible allowed their development, maturation and eruption indicating that stem cells could be used in the future for the replacement of missing teeth in humans.

\section{Dental Follicle Precursor Cells (DFPCs)}

Dental follicle (DF) contains progenitor cells that form the periodontium, i.e., cementum, periodontal ligament (PDL) and alveolar bone. Precursor cells have been isolated from human DFs of impacted third molars. These cells form low numbers of adherent clonogenic colonies when released from the tissue following enzymatic digestion [34].

DFPCs express the MSC marker STRO- 1 and human DFPCs have multipotential mesenchymal precursor cell properties. DFPCs differentiated toward multiple mesenchymal-derived cell types, such as cementoblasts, chondrocytes and adipocytes [35].

Cells in dental follicles (i) express markers such as Notch-1 and Nestin, suggesting the presence of undifferentiated cells, (ii) form colony forming unit-fibroblast (CFU-F) when attatched onto plastic surface, (iii) show a typical fibroblastlike morphology, (iv) express Nestin, Notch-1, collagen type I, bone sialoprotein (BSP), osteocalcin (OCN), and fibroblast growth factor receptor (FGFR)1-IIIC, [34] (v) demonstrate osteogenic differentiation capacity in vitro after induction, (vi) express STRO-1 and bone morphogenetic protein (BMP) receptors and express cementum attachment protein (CAP) and cementum protein-23 (CP-23) [35].

After transplantation into immunocompromised mice, DFPC transplants (i) express human specific transcripts for BSP, OCN, and collagen type I, (ii) genetic expression for BSP and OCN was increased more than 100 times, (iii) genetic expression was decreased for collagen type I transcripts, (iv) dentin, cementum or bone formation was not observed in the transplant in vivo [36].

DFPCs can also differentiate, form robust connective tissues and produce clusters of mineralized tissue $[37,38]$. These connective tissues form biological diaphragms. Here, typical markers for PDL and cementum were expressed, such as collagen type XII and the CAP [37].

\section{Dental Follicle Stem Cells (DFSC)}

Most people have an impacted third molar that does not occlude and subsequently have the impacted tooth extracted to avoid inflammation or orthodontic therapy. Such extracted teeth usually contain DF and are commonly discarded as medical waste. Hence, the DF is a candidate source for isolating MSC. Recent evidence has suggested that MSCs are present in the DF of the tooth germ at various stages of development in different species [34,39-43].

Appropriately triggered DF can differentiate toward a cementoblast, osteoblast, or PDL lineage. It has been demonstrated that human DFSCs are capable of differentiating into periodontal tissues in vivo [34], while immortalized DFSCs isolated from mouse incisor tooth germs have the capacity to generate periodontal tissue in vivo [40]. Gene expression patterns of DFSCs are consistent with those of PDL fibroblasts after culturing on collagen I matrix [44]. Several key genes, including DLX3 [37], transcription factor ZBTB16 and NR4A3, have been implicated in the switch from undifferentiated status to differentiation lineage [45]. The exact mechanisms of 
elaborate differentiation from stem cells to PDL, cementoblasts, and osteoblasts is expected to be elucidated in the future.

The existence of progenitor cells in bovine DF after transplantation has been reported [42]. Cultured bovine DFSCs at the root-forming stage, in combination with hydroxyapatite, successfully generated cementum tissues and fibroblasts in vivo. Interestingly, cementum formation was observed only at the interface of the hydroxyapatite beads in the implants. Unlike alveolar osteoblasts, DFSCs do not form bone tissue by this method. Although it is unclear whether DFSCs have the characteristics of MSC, they are clearly progenitor cells for cementoblasts [42]. Human DF progenitor cells were also reported in the DF of wisdom teeth at the root-formation stage [34]. Subsequently, mouse DFSCs at the crown-formation stage were shown to differentiate into osteogenic, adipogenic and chondrogenic lineages [46], while rat DFSCs have the capacity for osteogenesis, adipogenesis and neurogenesis but not chondrogenesis [39]. Thereafter, postnatal MSCs from human dental tissue such as DF at the apex of tooth root, PDL and dental pulp were isolated and compared to various other dental stem cells. The results showed that DFSCs have excellent proliferation rates and a capacity for osteogenesis and adipogenesis [43]; however, their capacity for chondrogenesis remains unknown.

DFSCs have been isolated from the follicle of human third molars and express the stem cell markers Notch1, STRO-1 and Nestin [34]. STRO-1 positive DFSC can differentiate into cementoblasts in vitro [35] and are able to form cementum in vivo. [42]. In addition, immortalized dental follicle cells were transplanted into immune-deficient mice and were able to recreate a new PDL-like tissue after 4 weeks [40]. It has been proved that enamel matrix derivatives (EMD) activated human dental follicle stem cells (hDFSCs) toward the cemento- blastic phenoltype. hDFSCs acquired cementoblast features under stimulation of BMP-2/-7 and EMD in vitro [35]. The three main lineages were highly undifferentiated state of PDL-type lineage and cementoblastic or alveolar bone osteoblastic lineage. The profound cellular heterogeneity of DFSCs suggests that heterogeneous cellular constituents might play a role in tissue regeneration as much as the individual lineages might do [46].

\section{Stem Cells from Human Exfoliated Deciduous Teeth (SHED)}

The isolation of post-natal stem cells from an easily accessible source is indispensable for tissue engineering and clinical applications. The isolation of mesenchymal progenitors from the pulp of human deciduous incisors were named SHED (Stem cells from Human Exfoliated Deciduous teeth) and exhibited a high plasticity since they could differentiate into neurons, adipocytes, osteoblasts and odontoblasts [23]. The discovery of SHED sheds a light on the intriguing possibility of using DPSC (Dental Pulp Stem Cells) for tissue engineering [47,48].

The obvious advantages of these cells are (i) higher proliferation rate compared with stem cells from permanent teeth
[23], (ii) easy to be expanded in vitro, (iii) high plasticity since they can differentiate into neurons, adipocytes, osteoblasts and odontoblasts, and (iv) readily accessible in young patient [23], especially suitable for young patients with mixed dentition [49]. SHEDs induced bone formation and produced dentin under in vivo conditions; and they were able to survive and migrate in murine brain after transplantation into immunecompromised animals [23].

SHEDs are distinctive with osteoinductive ability and high plasticity. When SHEDs are seeded in porous poly L-lactic acid (PLLA) prepared within human tooth slice scaffolds and transplanted into the subcutaneous tissue of immunedeficient mice, it is observed that they differentiated into odontoblast-like cells and showed morphologic characteristics resembling those of odontoblasts. Moreover, an increase in micro-vessel density was found in the co-implantation. It is also verified that the transplanted SHEDs were capable of differentiating into blood vessels that anastomosed with the host vasculature [50]. Thus SHEDs might be an ideal resource of stem cells to repair damaged tooth structures and induce bone regeneration.

The striking feature of these cells is that they are capable of inducing recipient murine cells to differentiate into boneforming cells, which is not a property attributed to DPSCs following transplantation in vivo. When single-colony-derived SHED clones were transplanted into immune-compromised mice, only one-fourth of the clones had the potential to generate ectopic dentin-like tissue equivalent to that generated by multicolony-derived SHED [23]. However, all single-colony derived SHED clones tested are capable of inducing bone formation in immune-compromised mice. While SHED could not differentiate directly into osteoblasts, they appeared to induce new bone formation by forming an osteoinductive template to recruit murine host osteogenic cells [23].

Ex vivo expanded SHED expressed STRO-1 and CD146 (MUC18), two early cell-surface markers for bone-marrowderived MSCs [51]. In addition, SHED expressed a variety of osteoblast/odontoblastic markers including Runx2, alkaline phosphatase (ALP), matrix extracellular phosphoglycoprotein (MEPE), BSP and dentin sialophosphoprotein (DSPP). After implantation into immunocompromised mice, with hydroxyapatitie/tricalcium phosphate (HA/TCP) as a carrier, SHED differentiated into odontoblast-like cells that formed small dentin-like structures. These results suggest that SHEDs are distinctive from DSPCs with respect to odontogenic differentiation and osteogenic induction [23].

SHED proliferate faster with greater population doublings than DPSCs and BMMSCs (Bone marrow derived mesenchymal stem cells) (SHED > DPSCs >BMMSCs). SHED form sphere-like clusters when cultured in neurogenic medium that either adhere to the culture dish or float freely in the culture medium, which can be dissociated by passage through needles and subsequently grown on $0.1 \%$ gelatin-coated dishes as 
individual fibroblastic cells. This phenomenon suggests a high proliferative capacity analogous to that of neural stem cells [23]. In a tooth slice model (horizontal section, $1 \mathrm{~mm}$ thick), it was shown that SHED seeded onto synthetic scaffolds seated into the pulp chamber space and formed odontoblastlike cells that localized against the existing dentin surface [50]. Investigators have isolated SHED and termed the cells 'immature DPSCs' (IDPSCs). IDPSCs express the embryonic stem cell markers Oct 4, Nanog, stage-specific embryonic antigens (SSEA-3, SSEA-4), and tumor recognition antigens (TRA-1-60 and TRA-1-81) [52].

\section{Stem Cells from Apical Papilla (SCAP)}

Apical papilla refers to the soft tissue at the apices of developing permanent teeth $[\mathbf{5 3}, \mathbf{5 4}]$. Apical papilla is more apical to the epithelial diaphragm, and there is an apical cell-rich zone lying between the apical papilla and the pulp [55]. Human SCAP have been isolated and their potential to differentiate into odontoblasts was compared to that of the PDL stem cells (PDLSCs) [53]. SCAPs exhibit a higher proliferative rate and appear more effective than PDLSC for tooth formation. Importantly, SCAP are easily accessible since they can be isolated from human third molars.

Ex vivo expanded SCAP (i) undergo odontogenic differentiation in vitro (ii) express lower levels of DSPP, MEPE, transforming growth factor $\beta$ receptor II (TGF $\beta$ RII), FGFR3, Flt-1 (VEGF receptor 1), Flg (FGFR1), and melanomaassociated glycoprotein (MUC18) in comparison with DPSCs, (iii) express CD24 which is down-regulated in response to osteogenic stimulation (iv) demonstrate the capacity to undergo adipogenic differentiation following induction in vitro $[53,56],(v)$ show positive staining for several neural markers [56] and (vi) generate a typical dentin-pulp like complex when transplanted into immunocompromised mice.

SCAP show characteristics similar to, but at the same time different from, those of DPSCs. SCAP appear to be the source of primary odontoblasts that are responsible for the formation of root dentin, whereas DPSCs are likely the source of replacement of odontoblasts that form reparative dentin. In a study with minipigs as a model, the surgical removal of the root apical papilla at an early developing stage halted root development, despite the pulp tissue being intact, whereas other roots of the tooth, containing apical papilla, maintained normal growth and development. Interestingly, only a combination of SCAPs and PDL stem cells induced the formation of a dental connective tissue, namely, the attachment of an artificial tooth crown in the alveolar bone [53].

SCAP along with PDLSCs are capable of generating a bioroot with PDL tissues. A mini-swine model was used, and the autologous SCAP and PDLSCs were loaded onto HA/TCP and gelfoam scaffolds, respectively, and implanted into sockets of the lower jaw. Three months later, the bio-root was formed in the porcine [53]. The bio-root structure was comprised of dentin randomly deposited by the SCAP. The bio-root was encircled with PDL tissue and appeared to have a natural relationship with the surrounding bone.

\section{Periodontal Ligament Stem Cells}

PDL itself contains progenitor cells; human stem cells have been isolated from PDL. They express stemness markers such as STRO-1, CD146 and they are able to form alizarin redpositive nodules and cementoblastic/osteoblastic markers (ALP, OCN, BSP) in vitro. These cells have been called PDLSC. They were the first candidate stem cells for periodontal tissue engineering [57] and have the potential to form collagen fibres and generate cementum/PDL-like structures in vivo serving as reliable sources for periodontal tissue reconstruction [57].

In vitro expanded PDLSCs were transplanted subcutaneously into the dorsal surfaces of immunocompromised mice using HA/TCP as a carrier and showed the capacity to differentiate into cementoblasts and to form cementum/PDL-like structures [58]. PDLSCs show the capacity to form collagen fibres connecting to the cementum-like tissue; these fibres are similar to Sharpey's fibres and they suggest the potential to regenerate $\mathrm{PDL}$ attachment.

An alternative line of research being actively pursued in periodontal regenerative research is the possibility of utilizing stem cell implantation to enhance regenerative outcomes. The principle of this approach is the isolation of MSC from bone marrow stroma or dental tissues, expansion of cell numbers ex vivo, and re-implantation of cells into the wound seeded into a suitable porous scaffold material or other matrix material, including collagen matrices, $\beta$-TCP and combined $\beta$-TCP-ECM scaffolds. The suggestion that cell re-implantation could be used in this way was first raised many years ago, although only recent advances have suggested that this could be a feasible approach. A number of animal studies have now reported the isolation, ex vivo expansion, and reimplantation of such cells derived from bone marrow or dental sources into periodontal wounds, where they appear to have been able to contribute to the regenerative processes [57-59]. Further studies are required to determine the full potential of this therapeutic approach. Studies may need to address the potential differences between differently derived stem cell sources, such as marrow stroma, PDL, and dental pulp cells. In addition, recent studies suggest that cells may retain their embryonic positional programming, and this may have profound effects on the ability of implanted cells to contribute appropriately to tissue regeneration at heterotopic sites $[60,61]$. This observation may have important implications for regenerative stem cell therapies in general, but its significance remains to be investigated further.

PDLSCs implanted into nude mice generated cementum/ PDL-like structures that resemble the native PDL as a thin layer of cementum that interfaced with dense collagen fibres, similar to Sharpey's fibers. After a three-week culture with an adipogenic-inductive cocktail, PDLSCs differentiated into Oilred-O-positive, lipid-laden adipocytes [58]. Upon four-week 
osteo/odontogenic inductions, alizarin-red-positive nodules formed in the PDLSC cultures, similar to MSCs and DPSCs $[58,62]$. Thus, the PDLSCs have the potential for forming periodontal structures, including the cementum and PDL.

A study in miniature pigs [57] showed that autologous PDLSCs are capable of forming bone, cementum and PDL if they are transplanted onto HA/TCP carrier into surgical, created periodontal defects. Precursor cells from human DFs of wisdom teeth have been isolated and characterized for their periodontal regeneration potential. These cells formed in vitro a membranous consisting of a connective-like matrix and a mesothelium-like cellular structure with nuclei of granular calcification. It has been demonstrated that immortalized mouse dental follicle cells are able to re-generate in vivo a PDL-like tissue [40].

Nondental stem cells such as embryonic stem cells [63], BMMSC [64], induced pluripotent stem cells (iPS) [65], adiposederived stem cells and cultured periosteum [66] have also been investigated for periodontal regeneration. These cells all have the potential for differentiating into osteoblasts, cementoblasts, and fibroblasts and to form cementum/PDLlike structures under appropriate conditions.

PDLSCs are also capable of differentiation to the cementoblastic lineage. The conditioned medium from developing apical tooth germ cells (APTG-CM) was shown to be able to provide a cementogenic micro-environment and induce differentiation of PDLSCs along the cementoblastic lineage. When transplanted into immunocompromised mice, the induced PDLSCs showed tissue-regenerative capacity to produce cementum/PDL-like structures, characterized by a layer of cementum-like mineralized tissues connected with PDL-like collagen fibres. This has important implications for periodontal engineering [67].

\section{Dental Pulp Stem Cells}

Although the regenerative capacity of the human dentin/ pulp complex is not well-understood, it is known that, upon injury, reparative dentin is formed as a protective barrier for the pulp [68]. Accordingly, one might anticipate that dental pulp contains the dentin progenitor cells that are responsible for dentin repair. Dental pulp contains proliferating cells that are analogous to bone cells, because they express osteogenic markers and respond to many growth factors for osteo/ odontogenic differentiation [69-71]. In addition, dental pulp cells are capable of forming mineral deposits with distinctive dentin-like crystalline structures $[\mathbf{2 2 , 7 2 , 7 3 ]}$. DPSCs have also been isolated from extracted human third molars $[22,74]$.

The dental pulp consists of a population of cells that contain lineage specific progenitor cells, as well as stem cells with multi-lineage differentiation capabilities $[\mathbf{7 5 , 7 6 ]}$. Dental pulp tissue is expected to be a cellular source for bone tissue repair and engineering [77] because when it is cultured in osteogenic-inducing media phenotypes similar to those of osteoblasts, as represented by the production of collagen type I, osteopontin, and BSP as well as mineralizing capability are formed $[\mathbf{7 4 , 7 8 ]}$.

Following physiological stimulation or injury, such as caries and operative procedures, stem cells in pulp may be mobilized to proliferate and differentiate into odontoblasts by morphogens released from the surrounding dentin matrix [79]. Tissue engineering with the triad of dental pulp progenitor/stem cells, morphogens and scaffolds may provide a useful alternative method for pulp-capping and root canal treatment [80].

Dental pulp contains highly proliferative cells that can be activated upon injury and undergo proliferation and differentiation toward osteoblastic phenotypes to provide for dentin repair. It is demonstrated that DPSC s can generate a dentin/pulp-like structure in vivo. When DPSCs are transplanted in conjunction with HA/TPC powder, a scaffold "odontoconductive", into immune-compromised mice, a collagenous matrix deposit is observed after 6 weeks [22]. The dentin matrix contains a reservoir of bioactive growth factors which can mediate these processes and the functional roles of members of the TGF- $\beta$ super-family in reparative dentinogenesis suggests a possible role in novel therapeutic mediators or tissue engineering solutions to dental regeneration. During dental disease or trauma, tissue damage and inflammation at sites of injury may compromise the ability of the pulpal ECM to mediate reparative events, and there may be advantages to providing a suitable matrix to encourage cell migration and differentiation at such sites. Recent studies using the tooth slice ex vivo culture system have demonstrated the ability of bioactive growth factor TGF-ss 1 contained within alginate hydrogels, to induce odontoblast-like cell differentiation within the dentin-pulp complex, with subsequent up-regulation of dentin matrix secretion [81].

An osteo-dentin like matrix was observed two weeks after subcutaneous implantation in rabbits, when poly (lacticco-glycolic acid) polymeric porous scaffolds grafted with DPSC were engineered. It is observed that cells formed mineralised-like structures even without the addition of any differentiation chemicals. These cells may undergo differentiation into hard tissue forming cells when provided with an appropriate substrate [82]. One important feature of pulp cells is their odontoblastic differentiation potential. Human pulp cells can be induced in vitro to differentiate into cells of odontoblastic phenotype, characterized by polarized cell bodies and accumulation of mineralized nodules $[\mathbf{7 2}, \mathbf{7 3}, \mathbf{8 3}]$. DPSCs isolated with enzyme treatment of pulp tissues form CFU-Fs with various characteristics $[\mathbf{2 2}, \mathbf{8 4}]$. There are different cell densities of the colonies, suggesting that each cell clone may have a different growth rate, as reported for BMMSCs [75]. Within the same colony, different cell morphologies and sizes may be observed. If seeded onto dentin, some DPSCs convert into odontoblast-like cells with a polarized cell body and a cell process extending into the existing dentinal tubules $[\mathbf{8 4 , 8 5}$.

To elucidate the self-renewal ability, investigators isolated 
cells from DPSC implants at two months post-subcutaneous implantation, by enzymatic digestion and subsequent expansion in vitro. The isolated cells from the DPSC implants were sorted by fluorescent-activated cell-sorting (FACS) with human beta1-integrin monoclonal antibody. The isolated human cells were re-implanted into immunodeficient mice for two months. The recovered secondary implants yielded the same dentin/pulp-like structures as the primary implants. Human DSPP was expressed in dentin-like structures, confirming the human origin of the odontoblast/pulp cells in the secondary DPSC implants [86].

\section{Signalling molecules}

Various growth factors and cytokines are conjugated to the ECM, such as BMP, fibroblast growth factor-2, interleukin-6, nsulin-like growth factor (IGF), platelet-derived growth factor (PDGF), transforming growth factor- $\beta 1$,etc. [87-90]. This co-localization acts as a storage pool of growth factors and may reduce growth factor degradation [91], protecting them from the local microenvironment, while facilitating the presentation of the growth factors to cell surface receptors [92]. Several studies have reported on roles for the ECM in cell proliferation, differentiation, migration, and apoptosis through interaction with cells and cell receptors [93-97].

During development, families of protein molecules govern the signaling that patterns the morphogenesis of tissues where cells become enmeshed into an ECM. Among the identified families, fibroblast growth factors (FGFs) (potent angiogenic factors and key players in cellular proliferation and differentiation) [98-100], hedgehog proteins (fundamental regulators of animal development) [101], members of the BMP superfamily (potent molecules for bone and cartilage induction) [102], Wingless- and Int-related proteins (Wnts) (believed to promote the maintenance and proliferation of stem cell) [103], platelet-derived growth factors (PDGF) (regulators of growth, division, and angiogenesis) [104], and vascular endothelial growth factors (VEGF) (signaling proteins for the de novo formation of blood vessels and the growth of blood vessels from pre-existing vasculature) [105] were evaluated for their contributions to craniofacial development, and avenues are currently being explored for their value when partnered with the stem-cell-based engineering of craniofacial defects $[106,107]$.

Among the various growth factors (GF), BMPs (mainly BMP-2 [108], BMP-4 [109], and BMP-7 [110]) have been more frequently applied in orofacial reconstruction. Since BMPs possess a well-established bone inducing effect in vivo, it is only recently that their effects have been exploited at the cellular level, where members of the family have been found to induce adipose-tissue-derived stem cells $[111,112]$. Major bone defects have been engineered by a combination of bone marrow stromal cells and BMP-7 [113], or by exclusive reliance on the growth factors $[114,115]$.

Platelet-rich plasma (PRP), used as a growth-enhancing substance, has been widely applied [116]. When PRP was used alone, the assorted mixture of wound-healing GFs demonstrated a solid foundation for soft-tissue healing [117], but not for hard-tissue healing, where its contribution to either alveolar bone or maxillary sinus augmentation continues to generate controversy [118]. While the GFs contained in the PRP are mitogenic, osteogenic, and angiogenic [119], the blend could lack the osteoinductive ingredient that, in the form of osteogenic cells, improved bone regeneration [120]. A controlled study in a canine model reported that the PRP/ cell construct regenerated alveolar defects comparably with a cancellous autograft [121].

BMPs have been implicated in tooth development, and the expression of BMP2 is increased during the terminal differentiation of odontoblasts [122,80]. BMP2 also induces a large amount of reparative dentin on the amputated pulp in vivo [123]. It has been suggested that BMP2 may regulate the differentiation of pulp cells into odontoblastic lineage and stimulate reparative dentin formation [80]. After treatment with BMP2, when human pulp progenitor/stem cells with HA/TCP as a scaffold were implanted into immunocompromised mice, tubular dentin was formed $[\mathbf{2 2}, \mathbf{7 5}]$. Beads soaked in human recombinant BMP2 induce the $\mathrm{mRNA}$ expression of DSPP, the differentiation marker of odontoblasts after implantation onto dental papilla in organ culture. The expression of DSPP was increased later, but not that of enamelysin/MMP20 (matrix metalloproteinase) and PHEX (phosphate-regulating gene with homologies to endopeptidases on X-chromosome). The enhanced expression of enamelysin/MMP20 and Phex on day 21 in pellet cultures, compared with monolayer cultures, suggested that the differentiation of pulp cells into odontoblastic lineage was more advanced. BMP-2 and BMP-7 have been shown to stimulate regeneration of periodontal tissues, particularly bone and cementum, in a range of animal models including rodents, dogs, and non-human primates [124-127]. Larger amounts of reparative dentin formation on the amputated pulp with a BMP2-supplemented pellet compared with a control pellet. The ECM of the pellet functions as a natural scaffold, which retains and releases BMPs [128].

Treatment of monolayer cultures of bovine pulp cells with rhBMP2 significantly increased the expression of a 1 (I)collagen and ALPase activity [122]. The increase in ALPase activity by rhBMP2 was higher in pellet cultures than in monolayer culture on day 14. The expression of DMP1 (dentin matrix protein), DSPP, enamelysin, and PHEX was more increased by rhBMP2 in pellet cultures than in monolayer cultures. The expression of $\mathrm{Cbfa} 1$ and $\mathrm{Cbfa} 3$ transcription factor has been reported in the dental papillae of mouse tooth germ at cap and bell stages, and later is limited in the odontoblastic layer [129].

Indeed, animal studies have demonstrated that the addition of a whole range of different factors, including BMP2, BMP-7, GDF-5 (BMP-14), PDGF, FGFs, IGF-1 and TGF- $\beta$ may be able to stimulate regeneration of the periodontal tissues [124,126,130-133]. 
Heylman et al. Journal of Regenerative Medicine \& Tissue Engineering 2013, http://www.hoajonline.com/journals/pdf/2050-1218-2-6.pdf

Table 1. Functions of ECM in tissues and of scaffolds in engineered tissues.

Functions of ECM Architectural, biological and mechanical features of scaffolds

\begin{tabular}{|c|c|c|}
\hline 1 & $\begin{array}{l}\text { To provide } \\
\text { structural support } \\
\text { for cells to attach } \\
\text { and proliferate }\end{array}$ & $\begin{array}{l}\text { (i) Biomaterials with binding sites for cells; } \\
\text { (ii) porous structure with interconnectivity } \\
\text { for cell migration and for nutrients diffusion; } \\
\text { (iii) biodegradation after some time upon } \\
\text { implantation }\end{array}$ \\
\hline 2 & $\begin{array}{l}\text { Mechanical } \\
\text { properties to } \\
\text { support tissues }\end{array}$ & $\begin{array}{l}\text { Scaffolds with adequate mechanical properties fill } \\
\text { up the defect and simulate that of the native tissue }\end{array}$ \\
\hline 4 & $\begin{array}{l}\text { Reservoirs of } \\
\text { growth factors }\end{array}$ & $\begin{array}{l}\text { Microstructures in scaffolds retain bioactive } \\
\text { agents i.e., growth factors in scaffold. Slow release } \\
\text { of growth factors over a prolonged duration. }\end{array}$ \\
\hline 5 & $\begin{array}{l}\text { To provides a } \\
\text { flexible physical } \\
\text { environment to } \\
\text { allow remodelling }\end{array}$ & $\begin{array}{l}\text { (i) Matrix design with controllable degradation } \\
\text { mechanisms and rates (ii) Porous microstructures } \\
\text { for nutrients and metabolites diffusion }\end{array}$ \\
\hline
\end{tabular}

The possible application of GDF-5 (BMP-14) for periodontal regeneration has been tested. Although GDF-5 is a member of the BMP family and shows osteoinductive potential, it has also been shown to be able to stimulate soft tissue repair in tendons and ligaments $[134,135]$. Initial animal studies of GDF-5-stimulated periodontal regeneration suggest that it may be able to increase regeneration without associated ankylosis $[135,136]$.

Pre-clinical investigations have revealed encouraging results with respect to the repair of periodontal defects with growth factors such as PDGF [137-140], BMPs [110,127], and fibroblast growth factor-2 [132,141,142]. PDGF has demonstrated the promise to regenerate bone in periodontal osseous defects, as shown in clinical trials when used alone $[130,143,144]$ or

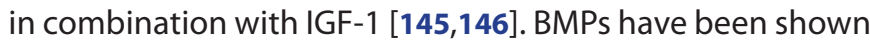
to induce bone regeneration in peri-implant and maxillary sinus-floor augmentation procedures $[147,148]$, extraction socket defects, [149-151] and mandibular discontinuity defects $[152,153]$. The use of BMPs for oral and craniofacial reconstruction has recently been reviewed $[\mathbf{8 0}, \mathbf{1 5 4}]$.

The local regulation of cellular function during wound healing is carried out by the interplay of cytokines and growth factors. Initial granulation tissue formation and neovascularization are regulated by release of factors including the platelet-derived growth factor (PDGF), together with expression of other factors that may include vascular endothelial growth factor (VEGF) and transforming growth factor beta (TGF- $\beta$ ) $[155,156]$. The osteoblastic differentiation cascade may be of particular importance when considering regeneration of alveolar bone and the other periodontal tissues. The key factor in the initiation of osteoblast differentiation is the commitment of osteogenic stem cells to an osteoblastic lineage. Osteoblastic commitmentis have been known to be regulated by the action of BMPs and more recently it has become clear that the BMP signalling pathway is intimately associated with the Wnt signalling pathway. Differentiation of these committed osteoprogenitor cells are then regulated by a range of factors that include fibroblast growth factors (FGFs) and PDGF, TGF- $\beta$, and the insulin-like growth factors, undergoing a series of amplifying divisions followed by increasing expression of genes regulating osteoblast differentiation, including the tissue-specific transcription factors runx2 and osterix [157].

Thus, physiologically, the balance between signalling molecules and their inhibitors is a key factor for the regulation of tissue homeostasis, repair, and regeneration. It is postulated that expression of growth factor inhibitors may be a limiting factor in the regenerative potential of the periodontium, particularly as the different tissue compartments (bone, PDL, gingivae) encroach on each other.

\section{Scaffolds}

During tissue engineering, cells and growth factors are combined with a porous biodegradable scaffold to repair and regenerate tissue. The scaffold acts as a temporary matrix while the cells secrete the ECM that is required for tissue regeneration. Scaffolds can be used to induce the formation of desired tissue following the in growth of cells from surrounding areas and as carriers for seeded autogeneous cells that are cultured in bioreactors and subsequently reimplanted in the patient [158]. The greatest challenges faced in tissue-engineered devices, regardless of tissue type, is promoting healing in three dimensions. Allowing angiogenesis throughout the scaffold is one of the most critical factors to the success of the scaffold.

Scaffolds have been fabricated for dental applications with a variety of natural and synthetic biomaterials, such as proteins [159], ceramics [160], metals [161], and polymers [162]. An appropriate scaffold for tissue engineering will be one that is created with biology in mind. The goal is the integration of the new tissue grown in the scaffold with the host tissue. Ideally, the scaffold provides a temporary pathway for regeneration and will degrade either during or after healing, thereby obviating the need to remove the material later and eliminating possible side effects associated with foreign materials in the body.

For tissue engineering, the ECM is required to act as a scaffold for cell attachment and to modulate cell proliferation and differentiation. The ECM is a mixture of proteins including collagens, proteoglycans, and laminins forming an elastic network surrounding most cells and tissue structures $[163,164]$. The composition, distribution and organization of the ECM is diverse, depending on tissue types and developmental stage $[165,166]$. The ECM binds to cell surface receptors, triggering changes in gene expression in the nucleus resulting in feedback mechanisms, which in turn modulate the ECM. The functions of the ECM and those of scaffolds in engineered tissues are tabulated in Table 1.

The ideal scaffold for generating new tissue should (i) be biocompatible, biodegradable and non-toxic, (ii) support the attatchment, migration, proliferation and differentiation of cells and the synthesis of new matrix, (iii) have adequate 
mechanical strength to withstand physiological stresses and minimise stress shielding in the surrounding host bone [167], (iv) have an integral, interconnected porous network, (v) permit neovascularisation for tissue growth. Various other properties of scaffolds like pore size, pore shape, pore-wall thickness, pore interconnectivity, pore-wall surface area, porosity, surface morphology, rate of degradation, surface chemistry, and mechanical stability affect bone healing.

\section{Biomaterials Applied for Tissue Engineering}

Over the last century, biocompatible materials such as metals, ceramics and polymers have been extensively used for surgical implantation. However, metals and ceramics are not biodegradable and their capability to be processed is very limited. Thus they cannot be used as effective scaffolds. Polymer materials have been widely used for tissue engineering because of easy control over biodegradability and processability. There are two kinds of polymer materials: synthetic polymer and naturally derived polymers [168-173]. The main biodegradable synthetic polymers include polyesters, polyanhydride, polycaprolactone, polycarbonate, polyfumarate and polyorthoester [174-179]. The polyesters such as poly(glycolic acid) (PGA), poly(lactic acid) (PLA), and their copolymer of poly [lactic-co-(glycolic acid)] (PLGA) are most commonly used for tissue engineering. The naturally derived polymers include proteins of natural extracellular matrices such as collagen and glycosaminoglycan, alginic acid, chitosan, Matrigel and polypeptides, etc. [180-184].

The naturally derived polymer materials are biodegradable and possess known cell-binding sites. Potential disadvantages include the level of immunogenicity, the speed of degradation, and a perceived limited ability to tailor native matrix for specific properties. Matrigel, a well-known extract from the Engelbreth-Holm-Swarm sarcoma that is rich in basement membrane components [185], is widely used in basic science for the study of cell-matrix interactions and increasingly in tissue engineering, particularly in areas such as nerves [186], adipose tissue [187] and skeletal muscle [188]. Collagens synthesized by several cell types [189], are used in various formats such as gels, meshes, and sponges or in combination with slow-release gelatine microspheres as cell scaffolds for the engineering of tissues such as adipose tissue [190], blood vessels [191], and skin [192]. The mechanical strength of collagen scaffolds and the rate of absorption have been of concern $[189,193]$, resulting in the use of cross linking agents to alter the biomedical, thermal, and mechanical properties of collagen [193]. Other extracellular matrices used as scaffolds include fibrin and fibrinogen. $[187,194,195]$. A recent study focusing on the development of fibrin-based matrices reported that a modified fibrin/L1lg6 matrix could induce angiogenesis activity in human umbilical vein endothelial cells in vitro [196]. Studies looking at the addition of fibronectin to tissue engineering scaffolds suggest that fibronectin may be critical for scaffold vascularisation $[197,198]$.
Chitosan exhibits a wide range of properties that make it appropriate for tissue engineering applications, namely, its biodegradability, [199-201] biocompatibility, [202-204] antibacterial activity, $[\mathbf{2 0 5 , 2 0 6 ]}$ wound healing properties, $[207,208]$ and bioadhesive character [209]. One of the most important characteristics of chitosan, for tissue engineering applications, is its ability to be shaped into various structures, such as microspheres, [210] paste, [211] membranes, [212] sponges, [213-215] fibers, $[\mathbf{2 1 6 , 2 1 7 ]}$ and porous scaffolds [218-221]. It is a potent wound-healing accelerator, [222] possesses immunological activity, by activating macrophages, [223] produces cytokines [224] and inhibits infection [225].

Bone tissue engineering is the most important aspect of craniofacial tissue engineering. Porous scaffolds are designed to support the migration, proliferation, and differentiation of osteo-progenitor cells and aid in the organization of these cells in three dimensions. These scaffolds may be made from a wide variety of both natural and synthetic materials. Aside from autografts and allografts of cancellous and cortical bone, [226-228] naturally derived materials include cornstarch-based polymers, [229] chitosan (a polysaccharide derived from chitin, found in crab shells), [230,231] collagen, [232] and coral $[\mathbf{2 3 3}, \mathbf{2 3 4}]$. Of these materials, coral has proven to be an effective clinical alternative to autogenic and allogenic bone grafts for certain applications $[\mathbf{2 3 5 , 2 3 6 ]}$. Scaffolds created from marine coral exoskeletons that are hydrothermally converted to hydroxyapatite, the mineral component of bone, are used for the repair of metaphyseal long bone cyst and tumour defects, which occur at the metaphysis of long bones. Synthetic materials include inorganic materials such as calcium phosphates [237-239] and organic materials such as poly(phosphazenes), [240] poly(tyrosine carbonates), [241] poly(caprolactones) [242], poly(propylene fumarates) [243], and poly(a-hydroxy acids) [244-247]. Composites of inorganic and organic materials have also been successfully used to create scaffolds for bone grafts [248-250].

Poly(a-hydroxy acids) are the most commonly used polymeric materials for the creation of tissue-engineering scaffolds for bone. The most common of the poly (a-hydroxy acids) are poly(glycolic acid), poly(lactic acid) (PLA), and copolymers of poly(lactic-co-glycolic acid) (PLGA). The degradation products of these materials are easily metabolized and excreted.

\section{Hybridization of Scaffold Materials}

The synthetic biodegradable polymers are easily formed into desired shapes with relatively good mechanical strength. Their periods of degradation can also be manipulated by controlling the crystallinity, molecular weight, and copolymer ratio. The scaffolds derived from synthetic polymers however lack cellrecognition signals, and their hydrophobic property hinders smooth cell seeding. In contrast, naturally derived collagen has the potential advantages of specific cell interactions and hydrophilicity, but scaffolds constructed entirely of collagen 
have poor mechanical strength. Therefore, these two kinds of biodegradable polymers have been hybridized to combine the advantageous properties of both constitutes [251-254].

The wettability of a polymer scaffold is considered very important for homogeneous and sufficient cell seeding in three dimensions. Because biodegradable synthetic polymers are relatively hydrophobic, it is difficult to deliver a cell suspension in a manner that uniformly distributes transplanted cells throughout their porous scaffolds. Numerous techniques have been used to evenly seed cells in PLA- and PLGA-based porous scaffolds, such as prewetting the scaffold with ethanol solution and then replacing it with distilled water and cell Suspension, introducing hydrophilic poly(ethyl glycol) into the hydrophobic PLA and PLGA network, or hydrolysis $[255,256]$. Hybridization with collagen improved the wettability of synthetic sponges with water, which facilitated cell seeding.

Three-dimensional scaffolds for bone tissue engineering should be osteoconductive so that osteoblasts and osteoprogenitor cells can adhere, migrate, differentiate, and synthesize new bone matrix. Hydroxyapatite has frequently been used for implants, coatings, and scaffolds in bone tissue engineering $[\mathbf{2 5 7 , 2 5 8 ]}$. Hydroxy-apatite particulates have been incorporated into poly (a-hydroxyl acids) to construct hybrid three-dimensional porous scaffolds of poly(a-hydroxyl acids) and hydroxyapatite. The incorporated hydroxyapatite shows a good degree of biocompatibility and osteoconductivity. The osteoconductivity of hydroxyapatite can be further improved by associating a protein matrix with the mineral structure [259]. To mimic the unique structure of collagen and hydroxyapatite in natural bone, several kinds of hybrid biomaterials of collagen and hydroxyapatite have been developed [260-262].

\section{Nanofibrous Scaffolds}

Native ECM is a hierarchically organized nanocomposite. Understanding tissue organization from the molecular to the macroscopic level will likely guide the rational design of synthetic ECM substitutes [263]. Tissue engineering scaffolds should recapitulate this hierarchical organization.The ECM is the nanofibrous protein network that surroundscells in all tissues to support their many functions [264] and can be emulated with a nanofibrous polymer scaffold. The nanofibers can be designed to promote cell functions such as migration, adhesion, proliferation, differentiation, and tissue neogenesis [265]. The scaffold should have an internal interconnected porous network to allow for cellular integration into the scaffold among other functions. It can even be designed to release growth factors to tailor tissue development [266].

With recent advances in nanotechnology, insight into nanoscale organization is accumulating, and nanofibrous and nanocomposite scaffolds that attempt to mimic the nanoscale morphological features of natural ECM are being developed [267-269]. A recent development in calcium phosphatebased scaffolds has been the fabrication of nanofibres [270].
Nanometre-sized fibres have a large surface-area to volume ratio and can be processed so that they have high porosity. These features are advantageous because they permit the delivery of drugs or growth-factors and allow cell migration and nutrient diffusion. Nanofibrous scaffolds have been fabricated by three techniques: electrospinning, self-assembly, and phase separation. Nanofibrous scaffolds provide a cellular platform for bone formation. However, although calvarial defect models exist [271], bone regeneration research is often geared toward the engineering of long bones. Because of differing developmental origins and ossification processes of the cranial skeleton and appendicular skeleton [272], current approaches to the engineering of long bones may require some optimization to restore craniofacial bones.

Huang et al., used a nanofibrous self-assembling peptide amphiphile to support enamel formation [273]. Following injection of the peptide into a mouse incisor, the incisor was cultured in a kidney capsule for 8 weeks. Ordered crystalline hydroxyapatite was found in "pearls" near the incisor. These results suggest that self-assembling peptides could form initial stages of tooth development.

Ongoing research has begun to address the implantation of an engineered mandibular construct into a functional load-bearing model. Since both mass transport and mechanical properties depend upon 3D scaffold architecture, computational design techniques are needed to predict and ultimately optimize a microstructure to achieve the desired balance [274]. Architectural 3D scaffold design with the desired anatomical shape can be produced from image-based $[275, \mathbf{2 7 6}]$ or computer-aided design (CAD)-based approaches [277]. Scaffolds from these design approaches can then be built directly or indirectly by Solid Free-Form Fabrication (SFF) $[\mathbf{2 7 7}, \mathbf{2 7 8 , 2 7 4 ]}$, and have been applied in craniofacial

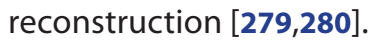

The ultimate goal is to use integrated design/fabricated scaffolds for functional mandibular condyle and other craniofacial reconstruction. Integrated design/fabrication methods not only make functional reconstruction possible, but also permit the testing of design hypotheses concerning scaffold/cell carrier combinations, eventually leading to optimal reconstruction methods.

DPSCs when seeded onto a phase-separated nanofibrous PLLA scaffold, nanofibers promoted attachment and proliferation of human DPSCs in vitro [281]. Electrospun nanofibrous polymer scaffolds have also supported adhesion of DPSCs $[\mathbf{2 8 2}, \mathbf{2 8 3}]$. Odontogenic differentiation of DPSCs was enhanced on the phase-separated nanofibrous scaffold compared with the solid-walled scaffold in vitro, shown by increased alkaline phosphatase (ALP) activity, dentin marker gene expression, and calcium deposition [281]. These nanofibers promoted collagen matrix deposition, dentin sialoprotein secretion, blood vessel in-growth, and mineralization in a subcutaneous implantation study of cultured DPSCscaffold constructs in nude mice [281]. Similar to osteogenic 
differentiation, odontogenic differentiation was enhanced by nanohydroxyapatiten electrospun nanofibers [284]. A mineral phase such as hydroxyapatite (HA) can also be incorporated into the nanofibrous scaffolds to form a composite bone matrix-mimicking scaffold [285]. Nano-Ha has been incorporated into a 3D phase-separated nanofibrous gelatine scaffold [286].

Studies on PDSC have shown good attachment and proliferation of periodontal ligament cells on electrospun PLGA [287] and electrospun gelatin [288] scaffolds, as well as periodontal ligament cells' osteogenic differentiation potential [287]. Furthermore, human periodontal ligament cells cultured on self-assembled peptide nanofibrous scaffolds promoted deposition of the main periodontal ligament ECM components, collagen type I and type III [159].

Strategies that involve using the scaffold itself to deliver cell growth factors such as vascular endothelial growth factor, [289] platelet-derived growth factor, [290] and recombinant human bone morphogenic protein $[291,292]$ have been investigated to enhance and accelerate the wound healing process. A biomimetic approach to improving cell attachment has been the modification of biomaterials with the arginineglycine-aspartic-acid (RGD)-peptide sequence [293]. Proteins with these sequences bind to cell surface receptors, facilitating the attachment of cells to substrata.

A range of materials have been suggested and employed as sustained delivery materials for growth factors [294]. These particularly include use of collagen matrices $[124,295]$, gelatin pellets [296], alloplastic calcium phosphate materials such as $\beta$-TCP and HA [130], and resorbable polymers such as PLA [297]. All of these materials tend to result in rapid initial loss of growth factor together with a slower prolonged release of factor over several days. Furthermore, it is clear that a delivery system can also serve as a scaffold or guided tissue regeneration membrane, and that manipulation of the material's properties can alter drug release kinetics, which may in turn affect biological responses. In addition to the testing and development or rhPDGF for use in periodontal regeneration, much of the research into growth factor application for periodontal regeneration has focused on the use of BMPs.

Many biodegradable biomaterials have been used and fabricated into various shapes for tissue engineering. These scaffolds showed promising results, guiding tissue development. The processing of the chosen materials into appropriate three-dimensional scaffolds with desired shapes and pore structures will be critical. Thus, scaffolds play a pivotal role in tissue engineering and are the focus of research in regenerative medicine.

\section{Conclusion}

The last few decades have seen rapid advances in our understanding of the genetic control of cellular behaviour during embryonic tooth development, leading to the programming and deprogramming of genes responsible for development of the dental tissues. This has provided for the foundation of knowledge by robust mechanistic data upon which we can build strategies for the tissue engineering and regeneration of teeth.

Most of the dental and craniofacial tissues are easily and readily accessible, thus presenting a convenient platform for, biologists, bioengineers, scientist and clinicians to test and apply tissue-engineered prototype. The impact of craniofacial tissue engineering extends beyond dental practice.

The optimal cell source, scaffold design, and the search for use of an appropriate multipotent or pluripotent stem cell in tissue engineering is an emerging concept. Certainly, many areas of stem cell research and their potential clinical applications are associated with controversies; therefore, it is important to address the ethical, legal, and social issues early. As more scientific knowledge will be gained from stem cell research, hopefully, some of the current ethical and technical concerns will be answered or removed in the future. Conversely, craniofacial tissue engineering could not have advanced to the current stage without the incorporation of interdisciplinary skill sets of stem cell biology, bioengineering, polymer chemistry, mechanical engineering, robotics, etc. with the ultimate goal of functional tissue restoration. Thus, craniofacial tissue engineering and regenerative dental medicine are integral components of regenerative medicine.

The scope of regenerative and tissue-engineering applications to dental science is immense; capable of bringing quantum advances in treatment strategies for patients. The need for high quality research in the basic sciences is imperative to ensure development of novel clinical treatment modalities that will revolutionise patient health care in the future.

The field of regenerative medicine is here to stay, as exemplified by the nascent but exponential growth of examples of translation from bench to bed side. The current hurdles are by no means insurmountable and, therefore, it is reasonable to assume to look forward to a more mature and highly rewarding field.

\section{Competing interests}

The authors declare that they have no competing interests.

\section{Authors' contributions}

\begin{tabular}{|l|c|c|c|}
\hline Authors' contributions & AP & YM & PN \\
\hline Research concept and design & -- & -- & -- \\
\hline Collection and/or assembly of data & $\sqrt{ }$ & $\sqrt{ }$ & $\sqrt{ }$ \\
\hline Data analysis and interpretation & -- & -- & -- \\
\hline Writing the article & $\sqrt{ }$ & $\sqrt{ }$ & $\sqrt{ }$ \\
\hline Critical revision of the article & $\sqrt{ }$ & $\sqrt{ }$ & $\sqrt{ }$ \\
\hline Final approval of article & -- & -- & -- \\
\hline Statistical analysis & -- & -- & -- \\
\hline
\end{tabular}

Publication history

Editor: Rolf Zehbe, Berlin Institute of Technology Berlin. 
Stephen Waldman D, Queen's University, Canada.

EIC: Scott Argraves, Medical University of South Carolina, USA.

Received: 14-Jun-2013 Revised: 03-Aug-2013

Accepted: 05-Sep-13 Published: 18-Sep-2013

\section{References}

1. Hollinger JO and Winn SR. Tissue engineering of bone in the craniofacial complex. Ann N Y Acad Sci. 1999; 875:379-85. | Article PubMed

2. Alsberg E, Hill EE and Mooney DJ. Craniofacial tissue engineering. Crit Rev Oral Biol Med. 2001; 12:64-75. | Article | PubMed

3. Abukawa H, Terai H, Hannouche D, Vacanti JP, Kaban LB and Troulis MJ. Formation of a mandibular condyle in vitro by tissue engineering. $J$ Oral Maxillofac Surg. 2003; 61:94-100. | Article | PubMed

4. Lynch SE, Genco RJ, Marx RE: Tissue engineering. In: Applications in maxillofacial surgery and periodontics. 1999 1st ed. Chicago, IL: Quintessence Publishing.

5. Mooney DJ, Powell C, Piana J and Rutherford B. Engineering dental pulp-like tissue in vitro. Biotechnol Prog. 1996; 12:865-8. | Article | PubMed

6. Murphy WL and Mooney DJ. Controlled delivery of inductive proteins, plasmid DNA and cells from tissue engineering matrices. J Periodontal Res. 1999; 34:413-9. | Article | PubMed

7. Buurma B, Gu K and Rutherford RB. Transplantation of human pulpal and gingival fibroblasts attached to synthetic scaffolds. Eur J Oral Sci. 1999; 107:282-9. | Article | PubMed

8. Tromans A. Developmental biology: a tadpole's tale. Nature. 2003; 425:250. | Article | PubMed

9. Young CS, Terada S, Vacanti JP, Honda M, Bartlett JD and Yelick PC. Tissue engineering of complex tooth structures on biodegradable polymer scaffolds. J Dent Res. 2002; 81:695-700. | Article | PubMed

10. Panetta NJ, Gupta DM, Slater BJ, Kwan MD, Liu KJ and Longaker MT. Tissue engineering in cleft palate and other congenital malformations. Pediatr Res. 2008; 63:545-51. | Article | PubMed

11. Caplan Al. Mesenchymal stem cells. J Orthop Res. 1991; 9:641-50. | Article I PubMed

12. Pittenger MF, Mackay AM, Beck SC, Jaiswal RK, Douglas R, Mosca JD, Moorman MA, Simonetti DW, Craig S and Marshak DR. Multilineage potential of adult human mesenchymal stem cells. Science. 1999; 284:143-7. | Article | PubMed

13. Petersen BE, Bowen WC, Patrene KD, Mars WM, Sullivan AK, Murase $\mathrm{N}$, Boggs SS, Greenberger JS and Goff JP. Bone marrow as a potential source of hepatic oval cells. Science. 1999; 284:1168-70. | Article | PubMed

14. Poulsom R, Alison MR, Cook T, Jeffery R, Ryan E, Forbes SJ, Hunt T, Wyles $S$ and Wright NA. Bone marrow stem cells contribute to healing of the kidney. J Am Soc Nephrol. 2003; 14 Suppl 1:S48-54. | Article | PubMed

15. Orlic D, Kajstura J, Chimenti S, Jakoniuk I, Anderson SM, Li B, Pickel J, McKay R, Nadal-Ginard B, Bodine DM, Leri A and Anversa P. Bone marrow cells regenerate infarcted myocardium. Nature. 2001; 410:701-5. | Article | PubMed

16. Brazelton TR, Rossi FM, Keshet $\mathrm{GI}$ and Blau HM. From marrow to brain: expression of neuronal phenotypes in adult mice. Science. 2000; 290:1775-9. | Article | PubMed

17. Mezey E, Chandross KJ, Harta G, Maki RA and McKercher SR. Turning blood into brain: cells bearing neuronal antigens generated in vivo from bone marrow. Science. 2000; 290:1779-82. | Article | PubMed

18. Mao JJ. Stem-cell-driven regeneration of synovial joints. Biol Cell. 2005; 97:289-301. | Article | PubMed

19. Christopherson KW, 2nd, Hangoc G, Mantel CR and Broxmeyer HE. Modulation of hematopoietic stem cell homing and engraftment by CD26. Science. 2004; 305:1000-3. | Article | PubMed

20. Hidalgo $A$ and Frenette PS. Enforced fucosylation of neonatal CD34+ cells generates selectin ligands that enhance the initial interactions with microvessels but not homing to bone marrow. Blood. 2005; 105:567-75. | Article | PubMed

21. Andreasen JO, Paulsen HU, Yu Z, Ahlquist R, Bayer T and Schwartz O. A long-term study of $\mathbf{3 7 0}$ autotransplanted premolars. Part I. Surgical procedures and standardized techniques for monitoring healing. Eur J Orthod. 1990; 12:3-13. | Article | PubMed

22. Gronthos S, Mankani M, Brahim J, Robey PG and Shi S. Postnatal human dental pulp stem cells (DPSCs) in vitro and in vivo. Proc Natl Acad Sci U S A. 2000; 97:13625-30. | Article | PubMed Abstract | PubMed Full Text

23. Miura M, Gronthos S, Zhao M, Lu B, Fisher LW, Robey PG and Shi S. SHED: stem cells from human exfoliated deciduous teeth. Proc Natl Acad Sci U S A. 2003; 100:5807-12. | Article | PubMed Abstract | PubMed Full Text

24. Chai $Y$ and Slavkin HC. Prospects for tooth regeneration in the 21st century: a perspective. Microsc Res Tech. 2003; 60:469-79. | Article | PubMed

25. Duailibi MT, Duailibi SE, Young CS, Bartlett JD, Vacanti JP and Yelick PC. Bioengineered teeth from cultured rat tooth bud cells. J Dent Res. 2004; 83:523-8. | Article | PubMed

26. Ohazama A, Modino SA, Miletich I and Sharpe PT. Stem-cell-based tissue engineering of murine teeth. J Dent Res. 2004; 83:518-22. | Article | PubMed

27. Harada $\mathrm{H}$, Kettunen $\mathrm{P}$, Jung HS, Mustonen T, Wang YA and Thesleff I. Localization of putative stem cells in dental epithelium and their association with Notch and FGF signaling. J Cell Biol. 1999; 147:105-20. | Article | PubMed Abstract | PubMed Full Text

28. Kawano S, Saito M, Handa K, Morotomi T, Toyono T, Seta Y, Nakamura $\mathrm{N}$, Uchida T, Toyoshima K, Ohishi M and Harada H. Characterization of dental epithelial progenitor cells derived from cervical-loop epithelium in a rat lower incisor. J Dent Res. 2004; 83:129-33. | Article I PubMed

29. Mitsiadis TA, Hirsinger E, Lendahl U and Goridis C. Delta-notch signaling in odontogenesis: correlation with cytodifferentiation and evidence for feedback regulation. Dev Biol. 1998; 204:420-31. | Article I PubMed

30. Mitsiadis TA, Barrandon O, Rochat A, Barrandon $Y$ and De Bari C. Stem cell niches in mammals. Exp Cell Res. 2007; 313:3377-85. | Article | PubMed

31. Smith CE and Warshawsky $\mathrm{H}$. Cellular renewal in the enamel organ and the odontoblast layer of the rat incisor as followed by radioautography using 3H-thymidine. Anat Rec. 1975; 183:523-61. | Article | PubMed

32. Bluteau G,Luder HU, De.Bari C, Mitsiadis T.A: Stem cells for Tissue Engineering. European Cells and Materials 2008 Vol 16:1-9.

33. Nakao K, Morita R, Saji Y, Ishida K, Tomita Y, Ogawa M, Saitoh M, Tomooka $Y$ and Tsuji T. The development of a bioengineered organ germ method. Nat Methods. 2007; 4:227-30. | Article | PubMed

34. Morsczeck C, Gotz W, Schierholz J, Zeilhofer F, Kuhn U, Mohl C, Sippel $\mathrm{C}$ and Hoffmann $\mathrm{KH}$. Isolation of precursor cells (PCs) from human dental follicle of wisdom teeth. Matrix Biol. 2005; 24:155-65. | Article I PubMed

35. Kemoun P, Laurencin-Dalicieux S, Rue J, Farges JC, Gennero I, ConteAuriol F, Briand-Mesange F, Gadelorge M, Arzate H, Narayanan AS, Brunel $G$ and Salles JP. Human dental follicle cells acquire cementoblast features under stimulation by BMP-2/-7 and enamel matrix derivatives (EMD) in vitro. Cell Tissue Res. 2007; 329:283-94. | Article | PubMed

36. Morsczeck C, Schmalz G, Reichert TE, Vollner F, Galler K and Driemel O. Somatic stem cells for regenerative dentistry. Clin Oral Investig. 2008; 12:113-8. | Article | PubMed

37. Morsczeck C, Moehl C, Gotz W, Heredia A, Schaffer TE, Eckstein N, Sippel $\mathrm{C}$ and Hoffmann $\mathrm{KH}$. In vitro differentiation of human dental follicle cells with dexamethasone and insulin. Cell Biol Int. 2005; 29:567-75. | Article | PubMed

38. Morsczeck C. Gene expression of runx2, Osterix, c-fos, DLX-3, DLX-5, 
and MSX-2 in dental follicle cells during osteogenic differentiation in vitro. Calcif Tissue Int. 2006; 78:98-102. | Article | PubMed

39. Yao $S$, Pan F, Prpic $V$ and Wise GE. Differentiation of stem cells in the dental follicle. J Dent Res. 2008; 87:767-71. | Article | PubMed Abstract | PubMed Full Text

40. Yokoi T, Saito M, Kiyono T, Iseki S, Kosaka K, Nishida E, Tsubakimoto T, Harada H, Eto K, Noguchi T and Teranaka T. Establishment of immortalized dental follicle cells for generating periodontal ligament in vivo. Cell Tissue Res. 2007; 327:301-11. | Article | PubMed

41. Handa K, Saito M, Tsunoda A, Yamauchi M, Hattori S, Sato S, Toyoda $M$, Teranaka T and Narayanan AS. Progenitor cells from dental follicle are able to form cementum matrix in vivo. Connect Tissue Res. 2002; 43:406-8. | Article | PubMed

42. Handa K, Saito M, Yamauchi M, Kiyono T, Sato S, Teranaka T and Sampath Narayanan A. Cementum matrix formation in vivo by cultured dental follicle cells. Bone. 2002; 31:606-11. | Article | PubMed

43. Jo YY, Lee HJ, Kook SY, Choung HW, Park JY, Chung JH, Choung YH, Kim ES, Yang HC and Choung PH. Isolation and characterization of postnatal stem cells from human dental tissues. Tissue Eng. 2007; 13:767-73. | Article | PubMed

44. Tsuchiya S, Honda MJ, Shinohara Y, Saito M and Ueda M. Collagen type I matrix affects molecular and cellular behavior of purified porcine dental follicle cells. Cell Tissue Res. 2008; 331:447-59. | Article | PubMed

45. Morsczeck C, Schmalz G, Reichert TE, Vollner F, Saugspier M, VialeBouroncle $S$ and Driemel $O$. Gene expression profiles of dental follicle cells before and after osteogenic differentiation in vitro. Clin Oral Investig. 2009; 13:383-91. | Article | PubMed

46. Luan $X$, Ito $Y$, Dangaria $S$ and Diekwisch TG. Dental follicle progenitor cell heterogeneity in the developing mouse periodontium. Stem Cells Dev. 2006; 15:595-608. | Article | PubMed Abstract | PubMed Full Text

47. Murray PE, Garcia-Godoy F and Hargreaves KM. Regenerative endodontics: a review of current status and a call for action. J Endod. 2007; 33:377-90. | Article | PubMed

48. Sloan AJ and Smith AJ. Stem cells and the dental pulp: potential roles in dentine regeneration and repair. Oral Dis. 2007; 13:151-7. | Article I PubMed

49. Nor JE. Tooth regeneration in operative dentistry. Oper Dent. 2006; 31:633-42. | Article | PubMed

50. Cordeiro MM, Dong Z, Kaneko T, Zhang Z, Miyazawa M, Shi S, Smith AJ and Nor JE. Dental pulp tissue engineering with stem cells from exfoliated deciduous teeth. J Endod. 2008; 34:962-9. | Article | PubMed

51. Shi S and Gronthos S. Perivascular niche of postnatal mesenchymal stem cells in human bone marrow and dental pulp. J Bone Miner Res. 2003; 18:696-704. | Article | PubMed

52. Kerkis I, Kerkis A, Dozortsev D, Stukart-Parsons GC, Gomes Massironi SM, Pereira LV, Caplan Al and Cerruti HF. Isolation and characterization of a population of immature dental pulp stem cells expressing OCT-4 and other embryonic stem cell markers. Cells Tissues Organs. 2006; 184:105-16. | Article | PubMed

53. Sonoyama W, Liu Y, Fang D, Yamaza T, Seo BM, Zhang C, Liu H, Gronthos $S$, Wang $C Y$, Wang $S$ and Shi $S$. Mesenchymal stem cell-mediated functional tooth regeneration in swine. PLoS One. 2006; 1:e79. | Article | PubMed Abstract | PubMed Full Text

54. Sonoyama W, Liu Y, Yamaza T, Tuan RS, Wang S, Shi S and Huang GT. Characterization of the apical papilla and its residing stem cells from human immature permanent teeth: a pilot study. J Endod. 2008; 34:166-71. | Article | PubMed Abstract | PubMed Full Text

55. Rubio D, Garcia-Castro J, Martin MC, de la Fuente R, Cigudosa JC, Lloyd $\mathrm{AC}$ and Bernad $\mathrm{A}$. Spontaneous human adult stem cell transformation. Cancer Res. 2005; 65:3035-9. | Article | PubMed

56. Abe $S$, Yamaguchi $S$ and Amagasa T. Multilineage cells from apical pulp of human tooth with immature apex. Oral Sci Int. 2007; 4:45-58. | Article

57. Liu Y, Zheng Y, Ding G, Fang D, Zhang C, Bartold PM, Gronthos S, Shi
S and Wang S. Periodontal ligament stem cell-mediated treatment for periodontitis in miniature swine. Stem Cells. 2008; 26:1065-73. | Article | PubMed Abstract | PubMed Full Text

58. Seo BM, Miura M, Gronthos S, Bartold PM, Batouli S, Brahim J, Young M, Robey PG, Wang CY and Shi S. Investigation of multipotent postnatal stem cells from human periodontal ligament. Lancet. 2004; 364:149-55. | Article | PubMed

59. Lin NH, Gronthos $S$ and Bartold PM. Stem cells and future periodontal regeneration. Periodontol 2000. 2009; 51:239-51. | Article | PubMed

60. Leucht P, Kim JB, Amasha R, James AW, Girod S and Helms JA. Embryonic origin and Hox status determine progenitor cell fate during adult bone regeneration. Development. 2008; 135:2845-54. | Article | PubMed

61. Rawlinson SC, McKay IJ, Ghuman M, Wellmann C, Ryan P, Prajaneh $\mathrm{S}$, Zaman G, Hughes FJ and Kingsmill VJ. Adult rat bones maintain distinct regionalized expression of markers associated with their development. PLoS One. 2009; 4:e8358. | Article | PubMed Abstract | PubMed Full Text

62. Shi S, Gronthos $S$, Chen S, Reddi A, Counter CM, Robey PG and Wang $\mathrm{CY}$. Bone formation by human postnatal bone marrow stromal stem cells is enhanced by telomerase expression. Nat Biotechnol. 2002; 20:587-91. | Article | PubMed

63. Inanc $B$, Elcin $A E$, Unsal E, Balos $K$, Parlar $A$ and Elcin $Y M$. Differentiation of human embryonic stem cells on periodontal ligament fibroblasts in vitro. Artif Organs. 2008; 32:100-9. | Article | PubMed

64. Kawaguchi $H$, Hirachi A, Hasegawa N, Iwata T, Hamaguchi $H$, Shiba $H$, Takata $\mathrm{T}$, Kato $\mathrm{Y}$ and Kurihara $\mathrm{H}$. Enhancement of periodontal tissue regeneration by transplantation of bone marrow mesenchymal stem cells. J Periodontol. 2004; 75:1281-7. | Article | PubMed

65. Duan X, Tu Q, Zhang J, Ye J, Sommer C, Mostoslavsky G, Kaplan D, Yang $P$ and Chen J. Application of induced pluripotent stem (iPS) cells in periodontal tissue regeneration. J Cell Physiol. 2011; 226:150-7. | Article | PubMed

66. Tobita M, Uysal AC, Ogawa R, Hyakusoku $\mathrm{H}$ and Mizuno H. Periodontal tissue regeneration with adipose-derived stem cells. Tissue Eng Part A. 2008; 14:945-53. | Article | PubMed

67. Yang ZH, Zhang XJ, Dang NN, Ma ZF, Xu L, Wu JJ, Sun YJ, Duan YZ, Lin Z and Jin $Y$. Apical tooth germ cell-conditioned medium enhances the differentiation of periodontal ligament stem cells into cementum/ periodontal ligament-like tissues. J Periodontal Res. 2009; 44:199-210. | Article | PubMed

68. Murray PE, About I, Franquin JC, Remusat M and Smith AJ. Restorative pulpal and repair responses. J Am Dent Assoc. 2001; 132:482-91. | Article | PubMed

69. Hanks CT, Sun ZL, Fang DN, Edwards CA, Wataha JC, Ritchie HH and Butler WT. Cloned 3 T6 cell line from CD-1 mouse fetal molar dental papillae. Connect Tissue Res. 1998; 37:233-49. | Article | PubMed

70. Unda FJ, Martin A, Hilario E, Begue-Kirn C, Ruch JV and Arechaga J. Dissection of the odontoblast differentiation process in vitro by a combination of FGF1, FGF2, and TGFbeta1. Dev Dyn. 2000; 218:480-9. | Article | PubMed

71. Ueno A, Kitase $Y$, Moriyama K and Inoue H. MC3T3-E1-conditioned medium-induced mineralization by clonal rat dental pulp cells. Matrix Biol. 2001; 20:347-55. | Article | PubMed

72. About I, Bottero MJ, de Denato P, Camps J, Franquin JC and Mitsiadis TA. Human dentin production in vitro. Exp Cell Res. 2000; 258:33-41. | Article I PubMed

73. Couble ML, Farges JC, Bleicher F, Perrat-Mabillon B, Boudeulle M and Magloire $\mathrm{H}$. Odontoblast differentiation of human dental pulp cells in explant cultures. Calcif Tissue Int. 2000; 66:129-38. | Article | PubMed

74. Shi S, Robey PG and Gronthos S. Comparison of human dental pulp and bone marrow stromal stem cells by cDNA microarray analysis. Bone. 2001; 29:532-9. | Article | PubMed

75. Gronthos S, Brahim J, Li W, Fisher LW, Cherman N, Boyde A, DenBesten P, Robey PG and Shi S. Stem cell properties of human dental pulp stem cells. J Dent Res. 2002; 81:531-5. | Article | PubMed 
76. Nakashima M, Mizunuma K, Murakami T and Akamine A. Induction of dental pulp stem cell differentiation into odontoblasts by electroporation-mediated gene delivery of growth/differentiation factor 11 (Gdf11). Gene Ther. 2002; 9:814-8. | Article | PubMed

77. Krebsbach PH and Robey PG. Dental and skeletal stem cells: potential cellular therapeutics for craniofacial regeneration. J Dent Educ. 2002; 66:766-73. I Article I PubMed

78. Kasugai S, Shibata S, Suzuki S, Susami T and Ogura H. Characterization of a system of mineralized-tissue formation by rat dental pulp cells in culture. Arch Oral Biol. 1993; 38:769-77. | Article | PubMed

79. Tziafas D, Smith AJ and Lesot H. Designing new treatment strategies in vital pulp therapy. J Dent. 2000; 28:77-92. | Article | PubMed

80. Nakashima $\mathrm{M}$ and Reddi $\mathrm{AH}$. The application of bone morphogenetic proteins to dental tissue engineering. Nat Biotechnol. 2003; 21:102532. | Article | PubMed

81. Dobie K, Smith G, Sloan AJ and Smith AJ. Effects of alginate hydrogels and TGF-beta 1 on human dental pulp repair in vitro. Connect Tissue Res. 2002; 43:387-90. I PubMed

82. El-Backly RM, Massoud AG, El-Badry AM, Sherif RA and Marei MK. Regeneration of dentine/pulp-like tissue using a dental pulp stem cell/poly(lactic-co-glycolic) acid scaffold construct in New Zealand white rabbits. Aust Endod J. 2008; 34:52-67. I Article I PubMed

83. Tsukamoto $Y$, Fukutani S, Shin-Ike T, Kubota T, Sato S, Suzuki Y and Mori M. Mineralized nodule formation by cultures of human dental pulp-derived fibroblasts. Arch Oral Biol. 1992; 37:1045-55. | Article | PubMed

84. Huang GT, Sonoyama W, Chen J and Park SH. In vitro characterization of human dental pulp cells: various isolation methods and culturing environments. Cell Tissue Res. 2006; 324:225-36. | Article I PubMed

85. Huang GT, Shagramanova K and Chan SW. Formation of odontoblastlike cells from cultured human dental pulp cells on dentin in vitro. J Endod. 2006; 32:1066-73. | Article | PubMed

86. Batouli S, Miura M, Brahim J, Tsutsui TW, Fisher LW, Gronthos S, Robey PG and Shi S. Comparison of stem-cell-mediated osteogenesis and dentinogenesis. J Dent Res. 2003; 82:976-81. | Article | PubMed

87. Dallas SL, Miyazono K, Skerry TM, Mundy GR and Bonewald LF. Dual role for the latent transforming growth factor-beta binding protein in storage of latent TGF-beta in the extracellular matrix and as a structural matrix protein. J Cell Biol. 1995; 131:539-49. | Article | PubMed Abstract | PubMed Full Text

88. Finkelman RD, Mohan S, Jennings JC, Taylor AK, Jepsen S and Baylink DJ. Quantitation of growth factors IGF-I, SGF/IGF-II, and TGF-beta in human dentin. J Bone Miner Res. 1990; 5:717-23. | Article | PubMed

89. Hodde JP, Record RD, Liang HA and Badylak SF. Vascular endothelial growth factor in porcine-derived extracellular matrix. Endothelium. 2001; 8:11-24. | Article | PubMed

90. Schnaper HW and Kleinman HK. Regulation of cell function by extracellular matrix. Pediatr Nephrol. 1993; 7:96-104. | Article | PubMed

91. Flaumenhaft R, Moscatelli D and Rifkin DB. Heparin and heparan sulfate increase the radius of diffusion and action of basic fibroblast growth factor. J Cell Biol. 1990; 111:1651-9. I Article I PubMed Abstract | PubMed Full Text

92. Roberts R, Gallagher J, Spooncer E, Allen TD, Bloomfield F and Dexter TM. Heparan sulphate bound growth factors: a mechanism for stromal cell mediated haemopoiesis. Nature. 1988; 332:376-8. | Article I PubMed

93. Boudreau N, Myers C and Bissell MJ. From laminin to lamin: regulation of tissue-specific gene expression by the ECM. Trends Cell Biol. 1995; 5:1-4. | Article | PubMed

94. Engvall $E$ and Ruoslahti $E$. Binding of soluble form of fibroblast surface protein, fibronectin, to collagen. Int J Cancer. 1977; 20:1-5. | Article | PubMed

95. Hauschka SD and Konigsberg IR. The influence of collagen on the development of muscle clones. Proc Natl Acad Sci U S A. 1966; 55:11926. | Article | PubMed Abstract | PubMed Full Text
96. Ingber D. Extracellular matrix and cell shape: potential control points for inhibition of angiogenesis. J Cell Biochem. 1991; 47:236-41. | Article I PubMed

97. Pierschbacher MD, Ruoslahti E, Sundelin J, Lind P and Peterson PA. The cell attachment domain of fibronectin. Determination of the primary structure. J Biol Chem. 1982; 257:9593-7. | Article | PubMed

98. Murakami S, Takayama S, Kitamura M, Shimabukuro Y, Yanagi K, Ikezawa K, Saho T, Nozaki T and Okada H. Recombinant human basic fibroblast growth factor (bFGF) stimulates periodontal regeneration in class II furcation defects created in beagle dogs. J Periodontal Res. 2003; 38:97-103. | Article I PubMed

99. Bottcher RT and Niehrs C. Fibroblast growth factor signaling during early vertebrate development. Endocr Rev. 2005; 26:63-77. | Article | PubMed

100. Crisera C, Teng E, Wasson KL, Heller J, Gabbay JS, Sedrak MF, Bradley JP and Longaker MT. Formation of in vitro murine cleft palate by abrogation of fibroblast growth factor signaling. Plast Reconstr Surg. 2008; 121:218-24. | Article | PubMed

101. Collins RT and Cohen SM. A genetic screen in Drosophila for identifying novel components of the hedgehog signaling pathway. Genetics. 2005; 170:173-84. | Article | PubMed Abstract | PubMed Full $\underline{\text { Text }}$

102. Urist MR. Bone: formation by autoinduction. Science. 1965; 150:893-9. | Article | PubMed

103. Willert K, Brown JD, Danenberg E, Duncan AW, Weissman IL, Reya T, Yates JR, 3rd and Nusse R. Wnt proteins are lipid-modified and can act as stem cell growth factors. Nature. 2003; 423:448-52. | Article | PubMed

104. Heidaran MA, Pierce JH, Yu JC, Lombardi D, Artrip JE, Fleming TP, Thomason A and Aaronson SA. Role of alpha beta receptor heterodimer formation in beta platelet-derived growth factor (PDGF) receptor activation by PDGF-AB. J Biol Chem. 1991; 266:20232-7. | Article | PubMed

105. Ferrara N and Gerber HP. The role of vascular endothelial growth factor in angiogenesis. Acta Haematol. 2001; 106:148-56. | PubMed

106. Etheridge SL, Spencer GJ, Heath DJ and Genever PG. Expression profiling and functional analysis of wnt signaling mechanisms in mesenchymal stem cells. Stem Cells. 2004; 22:849-60. | Article | PubMed

107. Risbud MV and Shapiro IM. Stem cells in craniofacial and dental tissue engineering. Orthod Craniofac Res. 2005; 8:54-9. | Article | PubMed

108. Dunn CA, Jin Q, Taba M, Jr., Franceschi RT, Bruce Rutherford R and Giannobile WV. BMP gene delivery for alveolar bone engineering at dental implant defects. Mol Ther. 2005; 11:294-9. | Article | PubMed Abstract I PubMed Full Text

109. Stadlinger B, Pilling E, Huhle M, Mai R, Bierbaum S, Scharnweber D, Kuhlisch E, Loukota R and Eckelt U. Evaluation of osseointegration of dental implants coated with collagen, chondroitin sulphate and BMP4: an animal study. Int J Oral Maxillofac Surg. 2008; 37:54-9. I Article | PubMed

110. Giannobile WV, Ryan S, Shih MS, Su DL, Kaplan PL and Chan TC. Recombinant human osteogenic protein-1 (OP-1) stimulates periodontal wound healing in class III furcation defects. J Periodontol. 1998; 69:129-37. | Article | PubMed

111. Diefenderfer DL, Osyczka AM, Reilly GC and Leboy PS. BMP responsiveness in human mesenchymal stem cells. Connect Tissue Res. 2003; 44 Suppl 1:305-11. | Article I PubMed

112. Cancedda R, Giannoni $P$ and Mastrogiacomo M. A tissue engineering approach to bone repair in large animal models and in clinical practice. Biomaterials. 2007; 28:4240-50. | Article | PubMed

113. Warnke PH, Wiltfang J, Springer I, Acil Y, Bolte H, Kosmahl M, Russo PA, Sherry E, Lutzen U, Wolfart S and Terheyden H. Man as living bioreactor: fate of an exogenously prepared customized tissueengineered mandible. Biomaterials. 2006; 27:3163-7. | Article | PubMed

114. Warnke PH, Springer IN, Acil Y, Julga G, Wiltfang J, Ludwig K, Russo PA, Sherry E, Sivananthan S, Hedderich J and Terheyden $H$. The mechanical 
integrity of in vivo engineered heterotopic bone. Biomaterials. 2006; 27:1081-7. | Article | PubMed

115. Schliephake H, Weich HA, Dullin C, Gruber R and Frahse S. Mandibular bone repair by implantation of rhBMP-2 in a slow release carrier of polylactic acid--an experimental study in rats. Biomaterials. 2008; 29:103-10. | Article | PubMed

116. Plachokova AS, Nikolidakis D, Mulder J, Jansen JA and Creugers NH. Effect of platelet-rich plasma on bone regeneration in dentistry: a systematic review. Clin Oral Implants Res. 2008; 19:539-45. | Article | PubMed

117. Anitua E, Aguirre JJ, Algorta J, Ayerdi E, Cabezas Al, Orive G and Andia I. Effectiveness of autologous preparation rich in growth factors for the treatment of chronic cutaneous ulcers. J Biomed Mater Res B Appl Biomater. 2008; 84:415-21. | Article | PubMed

118. Esposito M, Grusovin MG, Coulthard P and Worthington HV. The efficacy of various bone augmentation procedures for dental implants: a Cochrane systematic review of randomized controlled clinical trials. Int J Oral Maxillofac Implants. 2006; 21:696-710. | PubMed

119. Sanchez AR, Sheridan PJ and Kupp LI. Is platelet-rich plasma the perfect enhancement factor? A current review. Int J Oral Maxillofac Implants. 2003; 18:93-103. | PubMed

120. Yamada Y, Ueda M, Hibi H and Baba S. A novel approach to periodontal tissue regeneration with mesenchymal stem cells and platelet-rich plasma using tissue engineering technology: A clinical case report. Int J Periodontics Restorative Dent. 2006; 26:363-9. | Article | PubMed

121. Yamada Y, Ueda M, Naiki T and Nagasaka T. Tissue-engineered injectable bone regeneration for osseointegrated dental implants. Clin Oral Implants Res. 2004; 15:589-97. | Article | PubMed

122. Nakashima $M$, Nagasawa $H$, Yamada $Y$ and Reddi $A H$. Regulatory role of transforming growth factor-beta, bone morphogenetic protein-2, and protein- 4 on gene expression of extracellular matrix proteins and differentiation of dental pulp cells. Dev Biol. 1994; 162:18-28. | Article I PubMed

123. Nakashima M. Induction of dentin formation on canine amputated pulp by recombinant human bone morphogenetic proteins (BMP)-2 and -4. J Dent Res. 1994; 73:1515-22. | Article | PubMed

124. King GN, King N, Cruchley AT, Wozney JM and Hughes FJ. Recombinant human bone morphogenetic protein-2 promotes wound healing in rat periodontal fenestration defects. J Dent Res. 1997; 76:1460-70. | Article | PubMed

125. Ripamonti U, Heliotis M, van den Heever B and Reddi AH. Bone morphogenetic proteins induce periodontal regeneration in the baboon (Papio ursinus). J Periodontal Res. 1994; 29:439-45. | Article | PubMed

126. Ripamonti U, Heliotis M, Rueger DC and Sampath TK. Induction of cementogenesis by recombinant human osteogenic protein-1 (hop-1/ bmp-7) in the baboon (Papio ursinus). Arch Oral Biol. 1996; 41:121-26. | Article | PubMed

127. Sigurdsson TJ, Lee MB, Kubota K, Turek TJ, Wozney JM and Wikesjo UM. Periodontal repair in dogs: recombinant human bone morphogenetic protein-2 significantly enhances periodontal regeneration. J Periodontol. 1995; 66:131-8. | Article | PubMed

128. Rutherford RB. BMP-7 gene transfer to inflamed ferret dental pulps. Eur J Oral Sci. 2001; 109:422-4. | Article | PubMed

129. Yamashiro $T$, Aberg $T$, Levanon $D$, Groner $Y$ and Thesleff I. Expression of Runx1, -2 and -3 during tooth, palate and craniofacial bone development. Gene Expr Patterns. 2002; 2:109-12. | Article | PubMed

130. Nevins M, Giannobile WV, McGuire MK, Kao RT, Mellonig JT, Hinrichs JE, McAllister BS, Murphy KS, McClain PK, Nevins ML, Paquette DW, Han TJ, Reddy MS, Lavin PT, Genco RJ and Lynch SE. Platelet-derived growth factor stimulates bone fill and rate of attachment level gain: results of a large multicenter randomized controlled trial. J Periodontol. 2005; 76:2205-15. | Article | PubMed

131. Ripamonti U, Herbst NN and Ramoshebi LN. Bone morphogenetic proteins in craniofacial and periodontal tissue engineering: experimental studies in the non-human primate Papio ursinus.
Cytokine Growth Factor Rev. 2005; 16:357-68. | Article | PubMed

132. Takayama S, Murakami S, Shimabukuro Y, Kitamura M and Okada H. Periodontal regeneration by FGF-2 (bFGF) in primate models. I Dent Res. 2001; 80:2075-9. | Article | PubMed

133. Giannobile WV and Somerman MJ. Growth and amelogenin-like factors in periodontal wound healing. A systematic review. Ann Periodontol. 2003; 8:193-204. | Article | PubMed

134. Tashiro T, Hiraoka H, Ikeda Y, Ohnuki T, Suzuki R, Ochi T, Nakamura K and Fukui N. Effect of GDF-5 on ligament healing. J Orthop Res. 2006; 24:71-9. | Article | PubMed

135. Kim TG, Wikesjo UM, Cho KS, Chai JK, Pippig SD, Siedler M and Kim CK. Periodontal wound healing/regeneration following implantation of recombinant human growth/differentiation factor-5 (rhGDF-5) in an absorbable collagen sponge carrier into one-wall intrabony defects in dogs: a dose-range study. J Clin Periodontol. 2009; 36:589-97. | Article I PubMed

136. Moore YR, Dickinson DP and Wikesjo UM. Growth/differentiation factor-5: a candidate therapeutic agent for periodontal regeneration? A review of pre-clinical data. J Clin Periodontol. 2010; 37:288-98. | Article | PubMed

137. Lynch SE, de Castilla GR, Williams RC, Kiritsy CP, Howell TH, Reddy MS and Antoniades HN. The effects of short-term application of a combination of platelet-derived and insulin-like growth factors on periodontal wound healing. J Periodontol. 1991; 62:458-67. | Article | PubMed

138. Rutherford RB, Niekrash CE, Kennedy JE and Charette MF. Plateletderived and insulin-like growth factors stimulate regeneration of periodontal attachment in monkeys. J Periodontal Res. 1992; 27:28590. | Article | PubMed

139. Giannobile WV, Finkelman RD and Lynch SE. Comparison of canine and non-human primate animal models for periodontal regenerative therapy: results following a single administration of PDGF/IGF-I. J Periodontol. 1994; 65:1158-68. | Article | PubMed

140. Giannobile WV. Periodontal tissue engineering by growth factors. Bone. 1996; 19:23S-37S. | Article | PubMed

141. Rossa C, Jr., Marcantonio E, Jr., Cirelli JA, Marcantonio RA, Spolidorio LC and Fogo JC. Regeneration of Class III furcation defects with basic fibroblast growth factor (b-FGF) associated with GTR. A descriptive and histometric study in dogs. J Periodontol. 2000; 71:775-84. | Article PubMed

142. Nakahara T, Nakamura T, Kobayashi E, Inoue M, Shigeno $K$, Tabata $Y$, Eto $K$ and Shimizu Y. Novel approach to regeneration of periodontal tissues based on in situ tissue engineering: effects of controlled release of basic fibroblast growth factor from a sandwich membrane. Tissue Eng. 2003; 9:153-62. | Article | PubMed

143. Camelo M, Nevins ML, Schenk RK, Lynch SE and Nevins M. Periodontal regeneration in human Class II furcations using purified recombinant human platelet-derived growth factor-BB (rhPDGF-BB) with bone allograft. Int J Periodontics Restorative Dent. 2003; 23:213-25. I PubMed

144. Nevins ML, Camelo M, Lynch SE, Schenk RK and Nevins M. Evaluation of periodontal regeneration following grafting intrabony defects with bio-oss collagen: a human histologic report. Int J Periodontics Restorative Dent. 2003; 23:9-17. I PubMed

145. Howell TH, Fiorellini JP, Paquette DW, Offenbacher S, Giannobile WV and Lynch SE. A phase I/II clinical trial to evaluate a combination of recombinant human platelet-derived growth factor-BB and recombinant human insulin-like growth factor-l in patients with periodontal disease. J Periodontol. 1997; 68:1186-93. | Article | PubMed

146. Patil AS, Sable RB and Kothari RM. Role of insulin-like growth factors (IGFs), their receptors and genetic regulation in the chondrogenesis and growth of the mandibular condylar cartilage. J Cell Physiol. 2012; 227:1796-804. | Article | PubMed

147. Boyne PJ, Marx RE, Nevins M, Triplett G, Lazaro E, Lilly LC, Alder M and Nummikoski P. A feasibility study evaluating rhBMP-2/absorbable collagen sponge for maxillary sinus floor augmentation. Int $\mathrm{J}$ 
Heylman et al. Journal of Regenerative Medicine \& Tissue Engineering 2013, http://www.hoajonline.com/journals/pdf/2050-1218-2-6.pdf

Periodontics Restorative Dent. 1997; 17:11-25. | Article | PubMed

148. Hanisch O, Tatakis DN, Rohrer MD, Wohrle PS, Wozney JM and Wikesjo UM. Bone formation and osseointegration stimulated by rhBMP-2 following subantral augmentation procedures in nonhuman primates. Int J Oral Maxillofac Implants. 1997; 12:785-92. | Article | PubMed

149. Howell TH, Fiorellini J, Jones A, Alder M, Nummikoski P, Lazaro M, Lilly $L$ and Cochran D. A feasibility study evaluating rhBMP-2/absorbable collagen sponge device for local alveolar ridge preservation or augmentation. Int J Periodontics Restorative Dent. 1997; 17:124-39. | Article | PubMed

150. Cochran DL, Jones AA, Lilly LC, Fiorellini JP and Howell H. Evaluation of recombinant human bone morphogenetic protein-2 in oral applications including the use of endosseous implants: 3-year results of a pilot study in humans. J Periodontol. 2000; 71:1241-57. | Article | PubMed

151. Fiorellini JP, Howell TH, Cochran D, Malmquist J, Lilly LC, Spagnoli D, Toljanic J, Jones A and Nevins M. Randomized study evaluating recombinant human bone morphogenetic protein-2 for extraction socket augmentation. J Periodontol. 2005; 76:605-13. | Article | PubMed

152. Boyne PJ, Nakamura A and Shabahang S. Evaluation of the long-term effect of function on rhBMP-2 regenerated hemimandibulectomy defects. Br J Oral Maxillofac Surg. 1999; 37:344-52. | Article | PubMed

153. Warnke PH, Springer IN, Wiltfang J, Acil Y, Eufinger $H$, Wehmoller M, Russo PA, Bolte H, Sherry E, Behrens E and Terheyden H. Growth and transplantation of a custom vascularised bone graft in a man. Lancet. 2004; 364:766-70. | Article | PubMed

154. Wikesjo UM, Polimeni $G$ and Qahash $M$. Tissue engineering with recombinant human bone morphogenetic protein-2 for alveolar augmentation and oral implant osseointegration: experimental observations and clinical perspectives. Clin Implant Dent Relat Res. 2005; 7:112-9. | Article | PubMed

155. Patil AS, Sable RB and Kothari RM. An update on transforming growth factor-beta (TGF-beta): sources, types, functions and clinical applicability for cartilage/bone healing. J Cell Physiol. 2011; 226:3094103. | Article | PubMed

156. Patil AS, Sable RB and Kothari RM. Occurrence, biochemical profile of vascular endothelial growth factor (VEGF) isoforms and their functions in endochondral ossification. J Cell Physiol. 2012; 227:1298308. | Article | PubMed

157. Hughes FJ, Turner W, Belibasakis $G$ and Martuscelli G. Effects of growth factors and cytokines on osteoblast differentiation. Periodontol 2000. 2006; 41:48-72. | Article | PubMed

158. Burg KJ, Porter S and Kellam JF. Biomaterial developments for bone tissue engineering. Biomaterials. 2000; 21:2347-59. | Article | PubMed

159. Kumada $Y$ and Zhang S. Significant type I and type III collagen production from human periodontal ligament fibroblasts in 3D peptide scaffolds without extra growth factors. PLoS One. 2010; 5:e10305. | Article | PubMed Abstract | PubMed Full Text

160. Miura M, Gronthos S, Zhao M, Lu B, Fisher LW, Robey PG and Shi S. SHED: stem cells from human exfoliated deciduous teeth. Proc Natl Acad Sci U S A. 2003; 100:5807-12. | Article | PubMed Abstract | PubMed Full Text

161. Lin Y, Gallucci GO, Buser D, Bosshardt D, Belser UC and Yelick PC Bioengineered periodontal tissue formed on titanium dental implants. J Dent Res. 2011; 90:251-6. | Article | PubMed Abstract | PubMed Full Text

162. Young CS, Terada S, Vacanti JP, Honda M, Bartlett JD and Yelick PC. Tissue engineering of complex tooth structures on biodegradable polymer scaffolds. J Dent Res. 2002; 81:695-700. | Article | PubMed

163. Gullberg $D$ and Ekblom P. Extracellular matrix and its receptors during development. Int J Dev Biol. 1995; 39:845-54. | Article I PubMed

164. Rosso F, Giordano A, Barbarisi M and Barbarisi A. From cell-ECM interactions to tissue engineering. J Cell Physiol. 2004; 199:174-80. | Article I PubMed

165. Chiquet-Ehrismann R, Matsuoka Y, Hofer U, Spring J, Bernasconi C and Chiquet $M$. Tenascin variants: differential binding to fibronectin and distinct distribution in cell cultures and tissues. Cell Regul. 1991; 2:927-38. | Pdf | PubMed Abstract | PubMed Full Text

166. Hunter DD, Murphy MD, Olsson CV and Brunken WJ. S-laminin expression in adult and developing retinae: a potential cue for photoreceptor morphogenesis. Neuron. 1992; 8:399-413. | Article | PubMed

167. M.J. Yaszemski, J.B. Oldham, L. Lu, and B.L. Currier: Bone Engineering, edited by J.E. Davies (em2 Inc., Toronto, 2000) p. 541.

168. Kim BS and Mooney DJ. Development of biocompatible synthetic extracellular matrices for tissue engineering. Trends Biotechnol. 1998; 16:224-30. | Article | PubMed

169. Freed LE, Vunjak-Novakovic G, Biron RJ, Eagles DB, Lesnoy DC, Barlow SK and Langer R. Biodegradable polymer scaffolds for tissue engineering. Biotechnology (N Y). 1994; 12:689-93. I PubMed

170. Thomson RC, Yaszemski MJ, Powers JM and Mikos AG. Fabrication of biodegradable polymer scaffolds to engineer trabecular bone. $J$ Biomater Sci Polym Ed. 1995; 7:23-38. | PubMed

171. Katz AJ, Llull R, Hedrick MH and Futrell JW. Emerging approaches to the tissue engineering of fat. Clin Plast Surg. 1999; 26:587-603, viii. I Article I PubMed

172. Temenoff JS and Mikos AG. Injectable biodegradable materials for orthopedic tissue engineering. Biomaterials. 2000; 21:2405-12. | Article I PubMed

173. Kim BS, Baez CE and Atala A. Biomaterials for tissue engineering. World J Urol. 2000; 18:2-9. | Article | PubMed

174. Burg KJ, Porter S and Kellam JF. Biomaterial developments for bone tissue engineering. Biomaterials. 2000; 21:2347-59. | Article | PubMed

175. Langer R. Biomaterials in drug delivery and tissue engineering: one laboratory's experience. Acc Chem Res. 2000; 33:94-101. | Article | PubMed

176. Dormer KJ and Gan RZ. Biomaterials for implantable middle ear hearing devices. Otolaryngol Clin North Am. 2001; 34:289-97. | Article I PubMed

177. Agrawal CM and Ray RB. Biodegradable polymeric scaffolds for musculoskeletal tissue engineering. J Biomed Mater Res. 2001; 55:14150. | Article | PubMed

178. Ma PX and Choi JW. Biodegradable polymer scaffolds with welldefined interconnected spherical pore network. Tissue Eng. 2001; 7:23-33. | Article | PubMed

179. Hutmacher DW, Schantz T, Zein I, Ng KW, Teoh SH and Tan KC. Mechanical properties and cell cultural response of polycaprolactone scaffolds designed and fabricated via fused deposition modeling. J Biomed Mater Res. 2001; 55:203-16. | Article | PubMed

180. Nehrer S, Breinan HA, Ramappa A, Young G, Shortkroff S, Louie LK, Sledge CB, Yannas IV and Spector M. Matrix collagen type and pore size influence behaviour of seeded canine chondrocytes. Biomaterials. 1997; 18:769-76. Biomaterials 1997, 18:769. | Article | PubMed

181. Nehrer S, Breinan HA, Ramappa A, Hsu HP, Minas T, Shortkroff S, Sledge CB, Yannas IV and Spector M. Chondrocyte-seeded collagen matrices implanted in a chondral defect in a canine model. Biomaterials. 1998; 19:2313-28. | Article | PubMed

182. Suh JK and Matthew HW. Application of chitosan-based polysaccharide biomaterials in cartilage tissue engineering: a review. Biomaterials. 2000; 21:2589-98. | Article | PubMed

183. Van Osch GJ, Van Der Veen SW, Burger EH and Verwoerd-Verhoef HL. Chondrogenic potential of in vitro multiplied rabbit perichondrium cells cultured in alginate beads in defined medium. Tissue Eng. 2000; 6:321-30. | Article | PubMed Abstract | PubMed Full Text

184. Rowley JA, Madlambayan G and Mooney DJ. Alginate hydrogels as synthetic extracellular matrix materials. Biomaterials. 1999; 20:45-53. | Article | PubMed

185. Kleinman HK and Martin GR. Matrigel: basement membrane matrix with biological activity. Semin Cancer Biol. 2005; 15:378-86. | Article I PubMed

186. Navarro X, Rodriguez FJ, Ceballos D and Verdu E. Engineering an artificial nerve graft for the repair of severe nerve injuries. Med Biol 
Eng Comput. 2003; 41:220-6. | Article I PubMed

187. Cassell OC, Morrison WA, Messina A, Penington AJ, Thompson EW, Stevens GW, Perera JM, Kleinman HK, Hurley JV, Romeo R and Knight $K R$. The influence of extracellular matrix on the generation of vascularized, engineered, transplantable tissue. Ann N Y Acad Sci. 2001; 944:429-42. | Article | PubMed

188. Powell CA, Smiley BL, Mills J and Vandenburgh HH. Mechanical stimulation improves tissue-engineered human skeletal muscle. Am J Physiol Cell Physiol. 2002; 283:C1557-65. I Article I PubMed

189. Rosso F, Marino G, Giordano A, Barbarisi M, Parmeggiani D and Barbarisi A. Smart materials as scaffolds for tissue engineering. J Cell Physiol. 2005; 203:465-70. I Article I PubMed

190. Kimura Y, Ozeki M, Inamoto T and Tabata Y. Time course of de novo adipogenesis in matrigel by gelatin microspheres incorporating basic fibroblast growth factor. Tissue Eng. 2002; 8:603-13. | Article | PubMed

191. He W, Yong T, Teo WE, Ma Z and Ramakrishna S. Fabrication and endothelialization of collagen-blended biodegradable polymer nanofibers: potential vascular graft for blood vessel tissue engineering. Tissue Eng. 2005; 11:1574-88. | Article | PubMed

192. Guerret S, Govignon E, Hartmann DJ and Ronfard V. Long-term remodeling of a bilayered living human skin equivalent (Apligraf) grafted onto nude mice: immunolocalization of human cells and characterization of extracellular matrix. Wound Repair Regen. 2003; 11:35-45. | Article | PubMed

193. Wang MC, Pins GD and Silver FH. Collagen fibres with improved strength for the repair of soft tissue injuries. Biomaterials. 1994; 15:507-12. | Article I PubMed

194. Hofer SO, Mitchell GM, Penington AJ, Morrison WA, RomeoMeeuw $\mathrm{R}$, Keramidaris $\mathrm{E}$, Palmer $\mathrm{J}$ and Knight KR. The use of pimonidazole to characterise hypoxia in the internal environment of an in vivo tissue engineering chamber. Br J Plast Surg. 2005; 58:1104-14. | Article | PubMed

195. Ye Q, Zund G, Benedikt P, Jockenhoevel S, Hoerstrup SP, Sakyama S, Hubbell JA and Turina M. Fibrin gel as a three dimensional matrix in cardiovascular tissue engineering. Eur J Cardiothorac Surg. 2000; 17:587-91. | Article | PubMed

196. Hall H, Baechi T and Hubbell JA. Molecular properties of fibrin-based matrices for promotion of angiogenesis in vitro. Microvasc Res. 2001; 62:315-26. | Article | PubMed

197. Bourdoulous S, Orend G, MacKenna DA, Pasqualini R and Ruoslahti E. Fibronectin matrix regulates activation of RHO and CDC42 GTPases and cell cycle progression. J Cell Biol. 1998; 143:267-76. | Article | PubMed Abstract | PubMed Full Text

198. Vogel V and Baneyx G. The tissue engineeting puzzle: a molecular perspective. Annu Rev Biomed Eng. 2003; 5:441-63. I Article I PubMed

199. Tomihata $\mathrm{K}$ and Ikada $\mathrm{Y}$. In vitro and in vivo degradation of films of chitin and its deacetylated derivatives. Biomaterials. 1997; 18:567-75. | Article | PubMed

200. Nordtveit R.J., Va^rum K.M., and Smidsrd O: Degradation of partially $\mathrm{N}$-acetylated chitosans with hen egg white and human lysozyme. Carbohydr Polym. 1996; 29:163-167. I Article

201. Varum KM, Myhr MM, Hjerde RJ and Smidsrod O. In vitro degradation rates of partially $\mathrm{N}$-acetylated chitosans in human serum. Carbohydr Res. 1997; 299:99-101. | Article | PubMed

202. Molinaro G, Leroux JC, Damas J and Adam A. Biocompatibility of thermosensitive chitosan-based hydrogels: an in vivo experimental approach to injectable biomaterials. Biomaterials. 2002; 23:2717-22. | Article I PubMed

203. Rucker M, Laschke MW, Junker D, Carvalho C, Schramm A, Mulhaupt R, Gellrich NC and Menger MD. Angiogenic and inflammatory response to biodegradable scaffolds in dorsal skinfold chambers of mice. Biomaterials. 2006; 27:5027-38. | Article | PubMed

204. Shin SY, Park HN, Kim KH, Lee MH, Choi YS, Park YJ, Lee YM, Ku Y, Rhyu IC, Han SB, Lee SJ and Chung CP. Biological evaluation of chitosan nanofiber membrane for guided bone regeneration. $J$ Periodontol. 2005; 76:1778-84. | Article | PubMed
205. Muzzarelli R, Tarsi R, Filippini O, Giovanetti E, Biagini G and Varaldo $\mathrm{PE}$. Antimicrobial properties of $\mathrm{N}$-carboxybutyl chitosan. Antimicrob Agents Chemother. 1990; 34:2019-23. | Article | PubMed Abstract | PubMed Full Text

206. No HK, Park NY, Lee SH and Meyers SP. Antibacterial activity of chitosans and chitosan oligomers with different molecular weights. Int J Food Microbiol. 2002; 74:65-72. I Article I PubMed

207. Biagini G, Bertani A, Muzzarelli R, Damadei A, DiBenedetto G, Belligolli A, Riccotti G, Zucchini $C$ and Rizzoli C. Wound management with N-carboxybutyl chitosan. Biomaterials. 1991; 12:281-6. | Article | PubMed

208. Azad AK, Sermsintham N, Chandrkrachang S and Stevens WF. Chitosan membrane as a wound-healing dressing: characterization and clinical application. J Biomed Mater Res B Appl Biomater. 2004; 69:216-22. | Article | PubMed

209. Bertram $U$ and Bodmeier R. In situ gelling, bioadhesive nasal inserts for extended drug delivery: in vitro characterization of a new nasal dosage form. Eur J Pharm Sci. 2006; 27:62-71. I Article I PubMed

210. Jameela SR, Misra A and Jayakrishnan A. Cross-linked chitosan microspheres as carriers for prolonged delivery of macromolecular drugs. J Biomater Sci Polym Ed. 1994; 6:621-32. | Article I PubMed

211. Maruyama M and Ito M. In vitro properties of a chitosan-bonded selfhardening paste with hydroxyapatite granules. J Biomed Mater Res. 1996; 32:527-32. I Article I PubMed

212. Muzzarelli R, Baldassarre V, Conti F, Ferrara P, Biagini G, Gazzanelli $G$ and Vasi V. Biological activity of chitosan: ultrastructural study. Biomaterials. 1988; 9:247-52. | Article | PubMed

213. Seol YJ, Lee JY, Park YJ, Lee YM, Young K, Rhyu IC, Lee SJ, Han SB and Chung CP. Chitosan sponges as tissue engineering scaffolds for bone formation. Biotechnol Lett. 2004; 26:1037-41. | Article | PubMed

214. Muzzarelli RA, Biagini G, Bellardini M, Simonelli L, Castaldini C and Fratto G. Osteoconduction exerted by methylpyrrolidinone chitosan used in dental surgery. Biomaterials. 1993; 14:39-43. | Article | PubMed

215. Lee YM, Park YJ, Lee SJ, Ku Y, Han SB, Choi SM, Klokkevold PR and Chung CP. Tissue engineered bone formation using chitosan/ tricalcium phosphate sponges. J Periodontol. 2000; 71:410-7. | Article I PubMed

216. Costa-Pinto AR, Correlo VM, Sol PC, Bhattacharya M, Charbord P, Delorme B, Reis RL and Neves NM. Osteogenic differentiation of human bone marrow mesenchymal stem cells seeded on melt based chitosan scaffolds for bone tissue engineering applications. Biomacromolecules. 2009; 10:2067-73. | Article | PubMed

217. Tuzlakoglu K, Alves CM, Mano JF and Reis RL. Production and characterization of chitosan fibers and 3-D fiber mesh scaffolds for tissue engineering applications. Macromol Biosci. 2004; 4:811-9. | Article I PubMed

218. Costa-Pinto AR, Salgado AJ, Correlo VM, Sol P, Bhattacharya M, Charbord P, Reis RL and Neves NM. Adhesion, proliferation, and osteogenic differentiation of a mouse mesenchymal stem cell line (BMC9) seeded on novel melt-based chitosan/polyester 3D porous scaffolds. Tissue Eng Part A. 2008; 14:1049-57. I Article I PubMed

219. Zhang Y, Ni M, Zhang $M$ and Ratner B. Calcium phosphate-chitosan composite scaffolds for bone tissue engineering. Tissue Eng. 2003; 9:337-45. | Article | PubMed

220. Ang T.H., Sultana F.S.A., Hutmacher D.W., Wong Y.S., Fuh J.Y.H., Mo X.M., Loh H.T., Burdet E., and Teoh S.H. Fabrication of 3D chitosanhydroxyapatite scaffolds using a robotic dispensing system. Mater Sci Eng. 2002; 20:35. | Article

221. Yin Y, Ye F, Cui J, Zhang F, Li X and Yao K. Preparation and characterization of macroporous chitosan-gelatin/beta-tricalcium phosphate composite scaffolds for bone tissue engineering. J Biomed Mater Res A. 2003; 67:844-55. I Article I PubMed

222. Prudden JF, Migel $P$, Hanson $P$, Friedrich $L$ and Balassa $L$. The discovery of a potent pure chemical wound-healing accelerator. Am J Surg. 1970; 119:560-4. | Article | PubMed

223. Peluso G, Petillo O, Ranieri M, Santin M, Ambrosio L, Calabro D, 
Avallone B and Balsamo G. Chitosan-mediated stimulation of macrophage function. Biomaterials. 1994; 15:1215-20. | Article | PubMed

224. Mori T, Okumura M, Matsuura M, Ueno K, Tokura S, Okamoto Y, Minami $S$ and Fujinaga T. Effects of chitin and its derivatives on the proliferation and cytokine production of fibroblasts in vitro. Biomaterials. 1997; 18:947-51. | Article | PubMed

225. Nishimura K, Nishimura S, Nishi N, Saiki I, Tokura S and Azuma I. Immunological activity of chitin and its derivatives. Vaccine. 1984; 2:93-9. | Article | PubMed

226. Chakkalakal DA, Strates BS, Garvin KL, Novak JR, Fritz ED, Mollner TJ and McGuire MH. Demineralized bone matrix as a biological scaffold for bone repair. Tissue Eng. 2001; 7:161-77. | Article | PubMed

227. Stevenson S. Enhancement of fracture healing with autogenous and allogeneic bone grafts. Clin Orthop Relat Res. 1998; 355:S239-46. | Article | PubMed

228. Delloye C, Simon P, Nyssen-Behets C, Banse X, Bresler F and Schmitt D. Perforations of cortical bone allografts improve their incorporation. Clin Orthop Relat Res. 2002; 396:240-7. I Article | PubMed

229. Gomes ME, Ribeiro AS, Malafaya PB, Reis RL and Cunha AM. A new approach based on injection moulding to produce biodegradable starch-based polymeric scaffolds: morphology, mechanical and degradation behaviour. Biomaterials. 2001; 22:883-9. | Article | PubMed

230. Madihally SV and Matthew HW. Porous chitosan scaffolds for tissue engineering. Biomaterials. 1999; 20:1133-42. | Article | PubMed

231. Suh JK and Matthew HW. Application of chitosan-based polysaccharide biomaterials in cartilage tissue engineering: a review. Biomaterials. 2000; 21:2589-98. | Article | PubMed

232. Rocha LB, Goissis $G$ and Rossi MA. Biocompatibility of anionic collagen matrix as scaffold for bone healing. Biomaterials. 2002; 23:449-56. I Article I PubMed

233. Petite $H$, Viateau V, Bensaid W, Meunier A, de Pollak C, Bourguignon $M$, Oudina K, Sedel L and Guillemin G. Tissue-engineered bone regeneration. Nat Biotechnol. 2000; 18:959-63. | Article | PubMed

234. Sartoris DJ, Gershuni DH, Akeson WH, Holmes RE and Resnick D. Coralline hydroxyapatite bone graft substitutes: preliminary report of radiographic evaluation. Radiology. 1986; 159:133-7. | Article | PubMed

235. Irwin RB, Bernhard M and Biddinger A. Coralline hydroxyapatite as bone substitute in orthopedic oncology. Am J Orthop (Belle Mead NJ). 2001; 30:544-50. | Article | PubMed

236. Vacanti CA, Bonassar LJ, Vacanti MP and Shufflebarger J. Replacement of an avulsed phalanx with tissue-engineered bone. $N$ Engl J Med. 2001; 344:1511-4. | Article | PubMed

237. T.J. Flatley, K.L. Lynch, and M. Benson: Recombined Xenograft of Cancellous Bone and Bone Morphogenetic Protein (BMP). Clin. Orthop. 1983, 179:246.

238. Goshima J, Goldberg VM and Caplan AI. The osteogenic potential of culture-expanded rat marrow mesenchymal cells assayed in vivo in calcium phosphate ceramic blocks. Clin Orthop Relat Res. 1991; 298311. | Article | PubMed

239. Kon E, Muraglia A, Corsi A, Bianco P, Marcacci M, Martin I, Boyde A, Ruspantini I, Chistolini P, Rocca M, Giardino R, Cancedda R and Quarto R. Autologous bone marrow stromal cells loaded onto porous hydroxyapatite ceramic accelerate bone repair in critical-size defects of sheep long bones. J Biomed Mater Res. 2000; 49:328-37. | Article | PubMed

240. Laurencin CT, El-Amin SF, Ibim SE, Willoughby DA, Attawia M, Allcock HR and Ambrosio AA. A highly porous 3-dimensional polyphosphazene polymer matrix for skeletal tissue regeneration. $J$ Biomed Mater Res. 1996; 30:133-8. | Article | PubMed

241. C.L. Lhommeau, H. Levene, S. Abramson, and J. Kohn: Preparation of highly interconnected porous, tyrosine-derived polycarbonate scaffolds. Tissue Eng. 1998, 4(4):468.

242. Zein I, Hutmacher DW, Tan KC and Teoh SH. Fused deposition modeling of novel scaffold architectures for tissue engineering applications.
Biomaterials. 2002; 23:1169-85. | Article | PubMed

243. Fisher JP, Holland TA, Dean D, Engel PS and Mikos AG. Synthesis and properties of photocross-linked poly(propylene fumarate) scaffolds. J Biomater Sci Polym Ed. 2001; 12:673-87. I PubMed

244. Ishaug-Riley SL, Crane-Kruger GM, Yaszemski MJ and Mikos AG. Three-dimensional culture of rat calvarial osteoblasts in porous biodegradable polymers. Biomaterials. 1998; 19:1405-12. | Article | PubMed

245. C.E. Holy, M.S. Shoichet, and J.E. Davies: Engineering threedimensional bone tissue in vitro using biodegradable scaffolds: investigating initial cell-seeding density and culture period. Cells Mater. 1997, 7(3):223.

246. C.M. Agrawal, D. Huang, J.P. Schmitz and K.A. Athanasiou. Elevated temperature degradation of a 50:50 copolymer of PLA-PGA. Tissue Eng. 1997; 3:345. | Article

247. Ma PX and Choi JW. Biodegradable polymer scaffolds with welldefined interconnected spherical pore network. Tissue Eng. 2001; 7:23-33. | Article | PubMed

248. Thomson RC, Yaszemski MJ, Powers JM and Mikos AG. Hydroxyapatite fiber reinforced poly(alpha-hydroxy ester) foams for bone regeneration. Biomaterials. 1998; 19:1935-43. | Article | PubMed

249. Marra KG, Szem JW, Kumta PN, DiMilla PA and Weiss LE. In vitro analysis of biodegradable polymer blend/hydroxyapatite composites for bone tissue engineering. J Biomed Mater Res. 1999; 47:324-35. | Article | PubMed

250. $P$ Ma PX, Zhang $R$, Xiao $G$ and Franceschi R. Engineering new bone tissue in vitro on highly porous poly(alpha-hydroxyl acids)/ hydroxyapatite composite scaffolds. J Biomed Mater Res. 2001; 54:284-93. | Article | PubMed

251. M. G. Dunn, L. D. Bellincampi, A. J. Tria and J. P. Zawadsky. Preliminary development of a collagen-PLA composite for ACL reconstruction. J. Appl. Polym. Sci. 1997; 63:1423-1428. I Article

252. Kaufmann PM, Heimrath S, Kim BS and Mooney DJ. Highly porous polymer matrices as a three-dimensional culture system for hepatocytes. Cell Transplant. 1997; 6:463-8. | Article | PubMed

253. G. Chen, T. Ushida and T. Tetsuya. Fabrication of PLGA-Collagen Hybrid Sponge. Chem. Lett. 1999; 7:561-562. | Article

254. Chen G, Ushida T and Tateishi T. A biodegradable hybrid sponge nested with collagen microsponges. J Biomed Mater Res. 2000; 51:273-9. | Article | PubMed

255. Mooney DJ, Park S, Kaufmann PM, Sano K, McNamara K, Vacanti JP and Langer R. Biodegradable sponges for hepatocyte transplantation. J Biomed Mater Res. 1995; 29:959-65. | Article | PubMed

256. Gao J, Niklason L and Langer R. Surface hydrolysis of poly(glycolic acid) meshes increases the seeding density of vascular smooth muscle cells. J Biomed Mater Res. 1998; 42:417-24. | Article | PubMed

257. Bakos D, Soldan M and Hernandez-Fuentes I. Hydroxyapatite-collagenhyaluronic acid composite. Biomaterials. 1999; 20:191-5. | Article | PubMed

258. Ma PX and Zhang R. Synthetic nano-scale fibrous extracellular matrix. J Biomed Mater Res. 1999; 46:60-72. | Article | PubMed

259. Rovira, R. Bareille, I. Lopez, F. Rouais, L. Bordenave, C. Rey, M. Rabaud: Preliminary report on a new composite material made of calcium phosphate, elastin peptides and collagens. J. Mater. Sci.: Mater. Med. 1993, 4:372.

260. Yaylaoglu MB, Yildiz C, Korkusuz F and Hasirci V. A novel osteochondral implant. Biomaterials. 1999; 20:1513-20. | Article | PubMed

261. Doi $Y$, Horiguchi T, Moriwaki Y, Kitago H, Kajimoto T and Iwayama $Y$. Formation of apatite-collagen complexes. J Biomed Mater Res. 1996; 31:43-9. | Article | PubMed

262. C. Du, F. Z. Cui, X. D. Zhu, K. de Groot: Formation of calcium phosphate/collagen composites through mineralization of collagen matrix. J. Biomed. Mater. Res. 1999, 44:407.

263. Goldberg M, Langer R and Jia X. Nanostructured materials for applications in drug delivery and tissue engineering. J Biomater Sci Polym Ed. 2007; 18:241-68. | Article | PubMed Abstract I PubMed Full 


\section{Text}

264. Ekblom P, Vestweber $D$ and Kemler R. Cell-matrix interactions and celladhesion during development. Annu Rev Cell Biol. 1986; 2:27-47. I Article

265. Ma PX. Biomimetic materials for tissue engineering. Adv Drug Deliv Rev. 2008; 60:184-98. | Article | PubMed Abstract | PubMed Full Text

266. Wei G, Jin Q, Giannobile WV and Ma PX. The enhancement of osteogenesis by nano-fibrous scaffolds incorporating rhBMP-7 nanospheres. Biomaterials. 2007; 28:2087-96. | Article | PubMed Abstract | PubMed Full Text

267. Goldberg M, Langer R and Jia X. Nanostructured materials for applications in drug delivery and tissue engineering. J Biomater Sci Polym Ed. 2007; 18:241-68.. | Article | PubMed Abstract | PubMed Full $\underline{\text { Text }}$

268. Murugan R and Ramakrishna S. Nano-featured scaffolds for tissue engineering: a review of spinning methodologies. Tissue Eng. 2006; 12:435-47. | Article | PubMed

269. Smith LA and Ma PX. Nano-fibrous scaffolds for tissue engineering. Colloids Surf B Biointerfaces. 2004; 39:125-31. | Article | PubMed

270. Kim HW and Kim HE. Nanofiber generation of hydroxyapatite and fluor-hydroxyapatite bioceramics. J Biomed Mater Res B Appl Biomater. 2006; 77:323-8. | Article | PubMed

271. Woo KM, Chen VJ, Jung HM, Kim TI, Shin HI, Baek JH, Ryoo HM and Ma PX. Comparative evaluation of nanofibrous scaffolding for bone regeneration in critical-size calvarial defects. Tissue Eng Part A. 2009; 15:2155-62. | Article | PubMed Abstract | PubMed Full Text

272. Mao JJ, Giannobile WV, Helms JA, Hollister SJ, Krebsbach PH, Longaker MT and Shi S. Craniofacial tissue engineering by stem cells. J Dent Res. 2006; 85:966-79. | Article | PubMed Abstract | PubMed Full Text

273. Huang Z, Newcomb CJ, Bringas P, Jr., Stupp SI and Snead ML. Biological synthesis of tooth enamel instructed by an artificial matrix. Biomaterials. 2010; 31:9202-11. | Article | PubMed Abstract | PubMed Full Text

274. Hollister SJ. Porous scaffold design for tissue engineering. Nat Mater. 2005; 4:518-24. | Article | PubMed

275. Hollister SJ, Levy RA, Chu TM, Halloran JW and Feinberg SE. An image-based approach for designing and manufacturing craniofacial scaffolds. Int J Oral Maxillofac Surg. 2000; 29:67-71. | Article | PubMed

276. Hollister SJ, Maddox RD and Taboas JM. Optimal design and fabrication of scaffolds to mimic tissue properties and satisfy biological constraints. Biomaterials. 2002; 23:4095-103. | Article | PubMed

277. Hutmacher DW, Sittinger M and Risbud MV. Scaffold-based tissue engineering: rationale for computer-aided design and solid free-form fabrication systems. Trends Biotechnol. 2004; 22:354-62. | Article | PubMed

278. Yeong WY, Chua CK, Leong KF and Chandrasekaran M. Rapid prototyping in tissue engineering: challenges and potential. Trends Biotechnol. 2004; 22:643-52. | Article | PubMed

279. Rohner D, Hutmacher DW, Cheng TK, Oberholzer M and Hammer B. In vivo efficacy of bone-marrow-coated polycaprolactone scaffolds for the reconstruction of orbital defects in the pig. J Biomed Mater Res $B$ Appl Biomater. 2003; 66:574-80. | Article | PubMed

280. Hollister SJ, Lin CY, Saito E, Schek RD, Taboas JM, Williams JM, Partee B, Flanagan CL, Diggs A, Wilke EN, Van Lenthe GH, Muller R, Wirtz T, Das $\mathrm{S}$, Feinberg SE and Krebsbach PH. Engineering craniofacial scaffolds. Orthod Craniofac Res. 2005; 8:162-73. | Article | PubMed

281. Wang J, Ma H, Jin X, Hu J, Liu X, Ni L and Ma PX. The effect of scaffold architecture on odontogenic differentiation of human dental pulp stem cells. Biomaterials. 2011; 32:7822-30. | Article | PubMed Abstract | PubMed Full Text

282. Deng XL, Xu MM, Li D, Sui G, Hu XY and Yang XP. Electrospun PLLA/ MWNTs/HA hybrid nanofiber scaffolds and their potential in dental tissue engineering. Key Engineering Materials Bioceramics. 2007; 330332:393-396. | Article

283. Xu MM, Mei F, Li D, Yang XP, Sui G and Deng XL, et al. Electrospunpoly(L-lacticacid)/nano-hydroxyapatite hybrid nanofibers and their potential in dental tissue engineering. Key Engineering Materials Bioceramics. 2007; 330-332:377-380. I Article

284. Yang X, Yang F, Walboomers XF, Bian Z, Fan M and Jansen JA. The performance of dental pulp stem cells on nanofibrous PCL/gelatin/ nHA scaffolds. J Biomed Mater Res A. 2010; 93:247-57. | Article | PubMed

285. Zhang R and Ma PX. Poly(alpha-hydroxyl acids)/hydroxyapatite porous composites for bone-tissue engineering. I. Preparation and morphology. J Biomed Mater Res. 1999; 44:446-55. | Article | PubMed

286. Liu X, Smith LA, Hu J and Ma PX. Biomimetic nanofibrous gelatin/ apatite composite scaffolds for bone tissue engineering. Biomaterials. 2009; 30:2252-8. | Article | PubMed Abstract | PubMed Full Text

287. Inanc $B$, Arslan $Y E$, Seker S, Elcin AE and Elcin YM. Periodontal ligament cellular structures engineered with electrospun poly(DL-lactide-coglycolide) nanofibrous membrane scaffolds. J Biomed Mater Res A. 2009; 90:186-95. | Article | PubMed

288. Zhang S, Huang Y, Yang X, Mei F, Ma Q, Chen G, Ryu S and Deng X. Gelatin nanofibrous membrane fabricated by electrospinning of aqueous gelatin solution for guided tissue regeneration. J Biomed Mater Res A. 2009; 90:671-9. | Article | PubMed

289. Murphy WL, Peters MC, Kohn DH and Mooney DJ. Sustained release of vascular endothelial growth factor from mineralized poly(lactideco-glycolide) scaffolds for tissue engineering. Biomaterials. 2000; 21:2521-7. | Article | PubMed

290. Shea LD, Smiley E, Bonadio J and Mooney DJ. DNA delivery from polymer matrices for tissue engineering. Nat Biotechnol. 1999; 17:551-4. | Article | PubMed

291. Whang K, Tsai DC, Nam EK, Aitken M, Sprague SM, Patel PK and Healy KE. Ectopic bone formation via rhBMP-2 delivery from porous bioabsorbable polymer scaffolds. J Biomed Mater Res. 1998; 42:491-9. | Article | PubMed

292. Zegzula HD, Buck DC, Brekke J, Wozney JM and Hollinger JO. Bone formation with use of rhBMP-2 (recombinant human bone morphogenetic protein-2). J Bone Joint Surg Am. 1997; 79:1778-90. | Article I PubMed

293. Hersel U, Dahmen C and Kessler H. RGD modified polymers: biomaterials for stimulated cell adhesion and beyond. Biomaterials. 2003; 24:4385-415. | Article | PubMed

294. Sigurdsson TJ, Nygaard L, Tatakis DN, Fu E, Turek TJ, Jin L, Wozney JM and Wikesjo UM. Periodontal repair in dogs: evaluation of rhBMP-2 carriers. Int J Periodontics Restorative Dent. 1996; 16:524-37. | PubMed

295. Rutherford RB, Ryan ME, Kennedy JE, Tucker MM and Charette MF. Platelet-derived growth factor and dexamethasone combined with a collagen matrix induce regeneration of the periodontium in monkeys. J Clin Periodontol. 1993; 20:537-44. | Article | PubMed

296. Talwar R, Di Silvio L, Hughes FJ and King GN. Effects of carrier release kinetics on bone morphogenetic protein-2-induced periodontal regeneration in vivo. J Clin Periodontol. 2001; 28:340-7. | Article | PubMed

297. Park YJ, Ku Y, Chung CP and Lee SJ. Controlled release of plateletderived growth factor from porous poly(L-lactide) membranes for guided tissue regeneration. J Control Release. 1998; 51:201-11. | Article | PubMed

\section{Citation:}

Patil AS, Merchant Y and Nagarajan P. Tissue

Engineering of Craniofacial Tissues - A Review. J Regen Med Tissue Eng. 2013; 2: 6.

http://dx.doi.org/10.7243/2050-1218-2-6 